Wyrwich, M., Stuetzer, M., Sternberg, R. (2016). Entrepreneurial role models, fear of failure, and institutional approval of entrepreneurship: A tale of two regions, Small Business Economics. 46(3), 467-492. doi: 10.1007/s11187-015-9695-4.

Link to published version of the article: http://link.springer.com/article/10.1007/s11187-015-9695-4

\title{
Entrepreneurial role models, fear of failure, and institutional approval of entrepreneurship: A tale of two regions
}

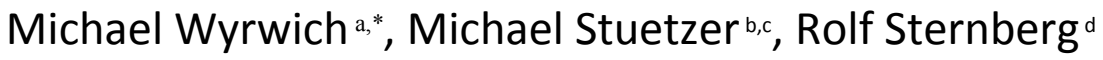

\begin{abstract}
Studies on the influence of entrepreneurial role models (peers) on the decision to start a firm argue that entrepreneurial role models in the local environment (1) provide opportunities to learn about entrepreneurial tasks and capabilities, and (2) signal that entrepreneurship is a favorable career option thereby reducing uncertainty that potential entrepreneurs face. However, these studies remain silent about the role of institutional context for these mechanisms. Applying an extended sender-receiver model, we hypothesize that observing entrepreneurs reduces fear of failure in others in environments where approval of entrepreneurship is high while this effect is significantly weaker in low approval environments. Taking advantage of the natural experiment from recent German history and using data from the Global Entrepreneurship Monitor Project (GEM), we find considerable support for our hypotheses.
\end{abstract}

Keywords: Fear of failure, role models, peer effect, entrepreneurial intentions, Global Entrepreneurship Monitor, East Germany

JEL classifications: D01, L26, M13, P20, R23, Z13

\section{Authors}

a - Michael Wyrwich

Friedrich Schiller University Jena

School of Economics and Business Administration

Carl-Zeiss Str. 3

07743 Jena (Germany)

michael.wyrwich@uni-jena.de

b - Baden-Wuerttemberg Cooperative State University

Coblitzallee 1-9

68193 Mannheim

c - Ilmenau University of Technology

Faculty of Economics and Business Administration

Ehrenbergstr. 29

98684 IImenau (Germany)

d - Institute of Economic and Cultural Geography

Leibniz Universität Hannover

Schneiderberg 50

30167 Hanover (Germany)

sternberg@wigeo.uni-hannover.de

* Corresponding author 


\section{Introduction}

Why are some people more likely to become entrepreneurs while others shy away? A great deal of research dealing with this question focuses on the influence of entrepreneurial role models (peers) on the decision to start a firm (e.g., Bosma et al., 2012; Chlosta et al., 2012; Fornahl, 2003; Kacperczyk, 2013; Minniti, 2005; Nanda and Sørenson, 2010; Sorenson and Audia, 2000). These studies argue that observing entrepreneurs in the local and social environment (e.g., family, workplace, university, and neighborhood) provides opportunities to learn about entrepreneurial tasks and capabilities, thereby reducing uncertainty that potential entrepreneurs face (for details, see Minniti, 2005). As Wagner and Sternberg (2004, p. 229) put it: "contacts with young entrepreneurs will reduce costs because they make it easier to get answers to lots of 'how to' type questions related to a start-up. We expect a positive impact of contact with such a 'role model."' In this respect, the knowledge acquired through social contact with an entrepreneur is supposed to reduce fear of entrepreneurial failure which might prevent people from starting firms. Aside from the demonstration effect, there is also a socio-psychological dimension of role modeling. In a nutshell, individuals may perceive entrepreneurship as a favorable career option from observing that one of their local peers is engaged in entrepreneurship (for details, see Fornahl, 2003). Accordingly, observing that peers can make it in entrepreneurship should reduce fearing to fail as an entrepreneur on the side of the observer. Building on these arguments, a number of studies have shown that the presence of entrepreneurial role models is positively related to entrepreneurial intentions (e.g., Krueger et al., 2000; van Auken et al., 2006) and to engaging in entrepreneurship (e.g., Arenius and Minniti, 2005; Davidsson and Honig, 2003; Dunn and Holtz-Eakin, 2000; Lafuente et al., 2007; Wagner and Sternberg, 2004).

Be as it may, previous research is more or less silent about the role of the regional environment in which entrepreneurial role modeling takes place even though entrepreneurship as such is regarded as a "regional event" (Feldman, 2001) in the literature. One of these crucial place-specific determinants of entrepreneurship is the institutional context (e.g., Baumol, 1990; Sobel, 2008). The lack of research on the institutional dimension of entrepreneurial role modeling and its effects on the perception of entrepreneurship and fear of failure in particular is surprising for two reasons. First, there is well-documented empirical evidence on differences with respect to entrepreneurial attitudes in the population across countries with different institutional background (e.g., Mueller and Thomas, 2001). Second, there is a lot of conceptual discussion on the crucial role of social acceptance or "social legitimacy" of entrepreneurship for actual transition to self-employment (e.g., Etzioni, 1987). Recently, Kibler et al. (2014) developed the concept of regional social legitimacy which is mainly grounded on the institutional theory of economic geography and sociology. They argue that regions develop specific cultural 
cognitive, normative, and regulative contexts that lead to various shared meanings and social perceptions of economic behavior (e.g., Gertler, 2010; Rodriguez-Pose, 2013; Scott, 1995; Suchmann, 1995). These shared regional meanings and social perceptions of economic behavior have the potential to determine individual perception and interpretation of the signals of entrepreneurial role models. Thus, our main research question is: Does the institutional environment, in particular the social approval of entrepreneurship, moderate the relationship between role models and individual perceptions of entrepreneurship and individual fear of failure? In this respect, we understand institutions as rules, laws, and constitutions which comprise the formal institutions as well as informal institutions which are represented by norms, conventions, codes of behavior, and the conduct of a society (e.g., North, 1990). We focus especially on informal institutions since we are comparing regions with different informal but equal formal institutions in our empirical analysis.

Investigating the role of institutions for the relationship between role models and individual perceptions of entrepreneurship like the perceived fear of failure is important for two reasons. Firstly, the individual perception of entrepreneurship is an important determinant for subsequent entrepreneurial activity. In particular, fear of failure has a strong negative relationship with entrepreneurial entry (e.g., Arenius and Minniti, 2005; Vaillant and Lafuente, 2007; Stuetzer et al., 2014). One explanation for this negative relationship comes from research on achievement orientation showing that avoiding failure is a strong human motivation (e.g., Conroy and Elliot, 2004; Elliot and Harackiewicz, 1996). If the institutional environment indeed plays a role in the formation of fear of failure, this might help explaining the persistence in regional differences in entrepreneurial activity, which has been observed in many Western market economies, such as the US (Acs and Mueller, 2008), the UK (Mueller et al., 2008), Germany (Fritsch and Mueller, 2007), the Netherlands (van Stel and Suddle, 2008) and Sweden (Andersson and Koster, 2011). Secondly, the promise of entrepreneurship as a driver for innovation and growth (Baumol, 2005) has spurred policy initiatives in many countries to increase the supply of entrepreneurs. For example, in entrepreneurship education, contacts to entrepreneurs shall reduce information ambiguity attached to entrepreneurship and arouse interest in non-entrepreneurs. This policy might be ineffective in regions with a low social approval of entrepreneurship. In these regions, contacts to entrepreneurs might not change the individual perception of entrepreneurship because the social norms and values are at odds with entrepreneurship. Thus, an assessment of social approval in the discussion of entrepreneurial role models can inform policy makers to develop proper policy initiatives tailored to region-specific needs.

This paper sets out to answer the research questions by examining the formation of one particular perceptional variable - fear of failure. Thereby, we take a socio-economic and geographical perspective on fear of failure. Following Arenius and Minniti (2005), we view fear of failure as the 
perceived risk of experiencing failure and its consequences when engaging in entrepreneurship. We do not argue that fear of failure reflects a general risk aversion. Nor do we claim that fear of failure prevents people to start a firm by hook or by crook (for a fruitful critical discussion, see Hayton et al., 2013 and Cacciotti and Hayton, 2015). We rather regard the formation of fear of failure as a contextspecific process that is affected by social interactions with entrepreneurs in the local environment and can negatively affect entrepreneurial propensity. Furthermore, we believe that these processes depend on the social legitimation of entrepreneurship in terms of the general local favorability of entrepreneurship as a career option (Etzioni, 1987). Thus, fear of failure has an institutional dimension to the extent that entrepreneurship in terms of starting a business is less accepted as a career option, and (failed) entrepreneurs face social stigmatization in less entrepreneurship approving institutional environments.

We start out by examining the effect of observing an entrepreneur on fear of failure. Based on a simple sender-receiver model, we argue that an entrepreneur (sender) transmits two signals to an observing non-entrepreneurial peer (receiver): (1) knowledge about entrepreneurial tasks and capabilities and (2) the attractiveness of entrepreneurship (e.g., by observing well-being and income) as a career option. Based on these general mechanisms one can derive that knowing other entrepreneurs should reduce other people's fear to fail in entrepreneurship. In essence, observing entrepreneurship allows (1) learning about entrepreneurial tasks and (2) acquiring entrepreneurial capabilities which should reduce fear to fail with respect to running an entrepreneurial venture. Thirdly, peers engaged in entrepreneurship signal the very feasibility purely by the fact of being in it (e.g., Sorenson and Audia, 2000) which accordingly should reduce one's fear of failure. In the second step, we extend the senderreceiver model with the concept of shared mental models (Denzau and North, 1994). Shared mental models emerge from a common cultural heritage of individuals and have a strong impact on how information is interpreted. In this respect, we argue that the social approval of entrepreneurship is a shared mental model and thus determines the perception and interpretation of entrepreneurial role models and information provided by the latter. This important aspect has not been addressed in the previous literature. We hypothesize that the cushioning influence of knowing an entrepreneur on the fear of failure is weaker in regions with low approval of entrepreneurship compared to high-approval regions. We test our hypotheses by combining individual-level data from the Global Entrepreneurship Monitor (GEM) project in Germany and regional-level data. Recent German history provides a natural experiment to test this interaction hypothesis as East Germany, with its socialist history and legacy, can be regarded as a region with a low approval of entrepreneurship, while West Germany can be seen as a high-approval area in relative terms (e.g., Alesina and Fuchs-Schuendeln, 2007; Bauernschuster et al., 2012; Runst, 2013). Our results provide reasonable support for our model, showing that observing 
an entrepreneur reduces fear of failure in West Germany but not among older East Germans that spent a considerable time of their life in socialism.

This paper contributes to the scholarly field of entrepreneurship in several ways. Most importantly, we combine ideas from research on the institutional environment with the literature on role models in order to illuminate the role of region-specific institutional context. Furthermore, we contribute to the ongoing discussion of why regional differences in entrepreneurial activity persist over long periods of time. We show that entrepreneurial role models do not positively affect individual entrepreneurial perceptions if individuals were exposed to an anti-entrepreneurial environment for most time of their life. The remainder of the article proceeds as follows. Section 2 presents our theory and hypotheses. Section 3 describes the data used for the analysis. Section 4 presents the results and discusses the findings. Section 5 concludes.

\section{Theoretical Framework}

\subsection{The entrepreneurial role model effect}

Previous theoretical and empirical analyses focused on the positive effect of entrepreneurship for vocational choice and on the evaluation of the prospects of an entrepreneurial career. These papers argue that the effect of role models is driven by social interaction and personal contact on the local level (e.g., Bosma et al., 2012; Chlosta et al., 2012; Fornahl, 2003; Kacperczyk, 2013; Lafuente et al., 2007; Malecki, 2009; Minniti, 2005; Nanda and Sørenson, 2010; Sorenson and Audia, 2000).

What makes the role model effect? Previous research has distinguished two different signals of entrepreneurial peers. First, entrepreneurs provide opportunities to learn about entrepreneurial tasks and capabilities. In particular, the presence of entrepreneurial role models in the social environment reduces the ambiguity that potential entrepreneurs may feel about starting a business and may help them acquire necessary information and entrepreneurial skills. This pattern can be regarded as a non-pecuniary externality (Minniti, 2005). Thus, observing successful entrepreneurs demonstrates to potential entrepreneurs, for instance, how to organize the resources and activities required for starting and running one's own venture more easily and increases individual self-confidence (e.g., Sorenson and Audia, 2000).

In addition to the learning mechanism, there is also a socio-psychological dimension of role modeling. In this respect, individuals may perceive entrepreneurship as an attractive career option from observing that a peer with whom they are socially interacting is engaged in entrepreneurial ac- 
tivities (for details, see Fornahl, 2003). This, in turn, leads to an increase in the number of entrepreneurs, which might increase social acceptance of entrepreneurship or "societal legitimation" (Etzioni, 1987). In turn, this might trigger a positive entrepreneurial choice. Hence, entrepreneurship becomes self-perpetuating over time, which is also indicated by empirical findings showing that the effect of past start-up activities on entrepreneurship is stronger if the level of new firm formation is high (Andersson and Koster, 2011; Chan et al., 2011; Fritsch and Wyrwich, 2014).

In technical terms, the functional principle of the role model effect is a simple sender-receiver model. The sender is an entrepreneur (peer) and the receiver is a non-entrepreneurial individual. The results of the aforementioned studies strongly suggest that the sender and receiver are typically located in the same region, mostly because proximity increases the frequency of face-to-face contacts and the intensity to observe and learn from others. Thus, sending and receiving of information can be regarded as a locally working process. The sender provides information about entrepreneurship which the receiver decodes and interprets. It is assumed that this information influences the receiver's attitude towards entrepreneurship and, ultimately, the occupational choice to either engage in entrepreneurship or to opt for paid employment.

Altogether, demonstration and legitimation effects related to social and economic interaction with entrepreneurs lead to (1) a reduction of ambiguity and (2) an increase in the perceived attractiveness of entrepreneurship as a career option. Both channels increase entrepreneurial intention as argued in the above cited papers that find a relationship between social contact to entrepreneurs and entrepreneurial intention. The same mechanisms should also contribute to a reduction of the fear of suffering from entrepreneurial failure because observing entrepreneurs allows learning from them which should decrease the observer's perceived risk of engaging in entrepreneurship. Observers can gain knowledge about entrepreneurial tasks and have the opportunity to acquire entrepreneurial capabilities. This should enhance the perceived ability to launch and run an entrepreneurial venture which is almost by definition accompanied by a lower fear of failure. In a similar vein, fear of failure should be reduced by perceiving entrepreneurship as an attractive career option due to the peer effect. In essence, the fact that friends and acquaintances can manage to be an entrepreneur induces the perception that one can be an entrepreneur as well. These arguments can be summarized in the following baseline hypothesis:

H1: Individuals observing entrepreneurs are less likely to fear entrepreneurial failure.

\subsection{The moderating effect of institutional context}

Our starting point is that the effectiveness of the demonstration and legitimation effect in the senderreceiver model depends on the willingness and the initial perception of entrepreneurship on the side 
of the observer to learn from the revealed information and the interpretation of the information. In this respect, we believe that the observer's approval of entrepreneurial behavior determines both patterns and therefore the outcome of the role modeling process. ${ }^{1}$ This aspect has not been addressed in the previous literature. This is surprising for two reasons. First, there is well-documented empirical evidence on cross-cultural differences with respect to entrepreneurial attitudes in the population (e.g., Mueller and Thomas, 2001). In essence, informal institutions-as reflected by norms and values with respect to entrepreneurship-can moderate the formation of entrepreneurial perception and fear of failure. Second, as previously mentioned, there is a lot of conceptual discussion on the crucial role of social acceptance or "social legitimacy" of entrepreneurship for actual transition to self-employment (e.g., Etzioni, 1987). In this respect, Kibler et al. (2014) developed the concept of regional social legitimacy, which is understood as a common perception, either positive or negative, of entrepreneurship. This concept is mainly grounded on the institutional theory of economic geography and sociology, arguing that regions develop specific cultural cognitive, normative, and regulative contexts that lead to various shared meanings and social perceptions of economic behavior (e.g., Gertler, 2010; RodriguezPose, 2013; Scott, 1995; Suchmann, 1995). Similarly, Westlund and Bolton (2003) developed the concept of local social capital, which can either facilitate or inhibit entrepreneurial activities.

Assessing cognitive learning processes helps to understand how social approval of entrepreneurship moderates the transmission process between entrepreneurial peers and the observer. One basic concept of cognitive learning that we refer to is that of "mental models." This framework was introduced into economics by Denzau and North (1994) and expands the simple sender-receiver model discussed above. According to these authors, mental models can be understood as internal representations that are created by one's cognitive systems, which are needed to interpret the environment. These mental representations determine individual decision making. Mental models evolve over time as they reflect feedback from new experiences. Such feedback may strengthen and confirm initial cognitive representations of the world or lead to modifications via learning. New experiences, and especially contact with the ideas of others in the local physical and socio-cultural environment, determine the shape of mental models.

As individuals gain different experience, mental models tend to diverge. However, the authors further argue that cultural heritage "...provides a means of reducing such divergence by encapsulating experience of past generations" (Denzau and North, 1994, p. 15). This heritage leads to the emergence of so-called shared mental models, which then greatly affect decision. Denzau and North (1994) stress that the perception and interpretation of information are, to a large degree, affected by values and

\footnotetext{
${ }^{1}$ The decoding of information in terms of understanding the demonstrated entrepreneurial activity is an additional technical aspect.
} 
beliefs as well as mental representations about the world among the listeners, or in other words: the shared mental model in the community of the observer. Thus, there is room for selective processing of information and a highly idiosyncratic interpretation of information.

We contend that social approval of entrepreneurship-as a shared mental model-also determines the perception and interpretation of entrepreneurship. Suppose a community where entrepreneurship as a career choice is widely approved. In such a community, the new experience of observing an entrepreneur will probably have a positive effect on the individual mental model or cognitive representation of entrepreneurship for the non-entrepreneurial observer. Contrariwise, observing an entrepreneur in a community with a low approval of entrepreneurship will hardly have a positive effect on the observer's mental model because the information does not fit to the shared mental model in the community and thus might receive little consideration. Non-pecuniary externalities associated with demonstrating entrepreneurship fall on deaf ears in environments with low approval. Besides, individuals socialized in a low-approval environment might cherry-pick negative aspects of entrepreneurship (e.g., long working hours, uncertainty and stress) that fit to the disapproving mental representation of entrepreneurship. Thus, signals provided by role models can be even adversely interpreted if they are not in line with the prevalent shared mental model in the region.

With respect to our variable of interest, we theorize that the social approval moderates the formation of fear of failure. In a region with low social approval of entrepreneurship, individuals are less willing to learn from entrepreneurs compared to individuals from high-approval regions (demonstration effect). Thus, the ambiguity regarding entrepreneurial tasks and entrepreneurial skills will remain at a higher level in low-approval regions than in high-approval regions where learning from entrepreneurs takes place more frequently. To the extent that learning about a task reduces the fear to engage in such a task, fear of failure will be lower in high-approval regions whereas fear of failure will be higher in low-approval regions.

Beside differences in the demonstration effect, there are likely also differences in the functioning of the legitimation effect of entrepreneurial role models. In low-approval regions where entrepreneurship is at odds with the shared mental model, being an entrepreneur is a less attractive career option compared to high-approval regions. In low-approval regions entrepreneurs have probably a low social standing in their communities. In the case that their businesses would fail, these people will probably face stigmatization and little support to re-enter entrepreneurship (Metzger, 2006) or even paid employment in the community (Landier, 2005). Observing entrepreneurial peers suffering from these negative consequences arguably will not increase and even might decrease the attractiveness of entrepreneurship as a career option. In other words, there are good reasons to fear entrepreneurial failure in low-approval regions. In contrast, entrepreneurs enjoy a higher social 
standing and failure is less stigmatized in high-approval regions. Observing peers engaged in entrepreneurship (even if some of their businesses fail) will arguably increase the attractiveness of entrepreneurship as a career option and reduce the fear of engaging in entrepreneurship.

Summarizing the above, observing an entrepreneur might reduce fear of failure much less (or may even increase it) in low approval areas than it would in high-approval. ${ }^{2}$ Taken together, we think that social approval of entrepreneurship moderates the effect of observing a entrepreneur on the reduction of fear of failure. This can be summarized in the following hypothesis:

H2: Observing an entrepreneur has a weaker effect on reducing fear of failure in regions with low approval of entrepreneurship than in high approval regions.

Our conceptual model is summarized in Figure 1.

*** Figure 1 about here $* * *$

\subsection{Setting}

In order to test our hypotheses, we make use of recent German history. The western part of the country can be regarded as an established market economy, whereas East Germany, the former German Democratic Republic (GDR), was marked by four decades of socialism before re-unification with West Germany in 1990. The formal institutional framework and, accordingly, the institutional conditions for entrepreneurship are more or less the same in both parts of the country since the complete formal institutional framework of West Germany was introduced in the eastern part of the country with reunification on October 3, 1990. However, there is ample evidence suggesting that the socialist legacy left an imprint on informal institutions as reflected by persisting differences with respect to norms and values like trust and solidarity (e.g., Brosig-Koch et al., 2011; Rainer and Siedler, 2009; van Hoorn and Maseland, 2010).

Socialism can be regarded as the economic system that is most hostile towards entrepreneurs (Earle and Sakova, 2000). The GDR was not an exception to this rule. Rather self-employment was strongly prohibited and allowed in only a few sectors like handicrafts and professional occupations (for details, Pickel, 1992). Entrepreneurship was perceived as a "bourgeois anachronism" (Thomas, 1996) and those that were self-employed in the GDR had to overcome mounting resistance (Wyrwich, 2015).

\footnotetext{
2 We assume that entrepreneurs send, on average, the same signals regardless of the underlying institutional approval. Relaxing this assumption should not be critical to our framework as long as differences in the kind of signals send are due to differences in approval of entrepreneurship. In this respect, entrepreneurs in low approval countries might share different signals or knowledge since they feel particularly conditioned and judged by their environment compared to high approval countries. This mechanism would be in line with our reasoning.
} 
Anti-capitalist indoctrination was also part of the curricula in schools and universities ("Staatsbürgerkunde" as subject in schools and "Marxismus-Leninismus" at the university level). Empirical evidence shows that East Germans have a higher level of state-reliance when compared to West Germans (e.g., Alesina and Fuchs-Schuendeln, 2007), which feeds back into lower preferences for entrepreneurship among Easterners (Bauernschuster et al., 2012; Runst, 2013). Furthermore, Obschonka et al. (2013) find that the Big Five personality characteristics differ between West and East Germans whereby the latter are less likely to have an entrepreneurial personality profile. These findings might be explained to a large degree by anti-capitalist indoctrination in socialism, leading to the formation of norms and values that are at odds with entrepreneurship (e.g., Earle and Sakova, 2000; Schwartz and Bardi, 1997; Smallbone and Welter, 2001). It is very likely that these entrepreneurship-hostile norms and values persisted to some degree after the German re-unification because norms and values are cannot be easily changed. ${ }^{3}$ The potential effects of socialism on mindset and lack of experience in entrepreneurship, make it likely that approval of entrepreneurship is comparatively low in East Germany. Approval of entrepreneurship in the German context, where formal institutions are similar in both parts of the country, refers to informal institutions that shape the perception and the extent of entrepreneurial activities. In particular it alludes to all informal institutions (norms, codes of behavior) that shape the "social legitimacy" of entrepreneurship. Thus, in regions with a high approval legitimacy of entrepreneurship is high whereas it is low in low approval environments (Etzioni, 1987; Kibler et al., 2014). In the German case, reports from the Global Entrepreneurship Monitor (GEM) project show that the perception of entrepreneurship is indeed less favorable in East Germany. To be more precise, East Germans are less likely to perceive favorable conditions for starting a firm, are more likely to assess their entrepreneurial skills to be low, and reveal a higher fear of failure than West Germans (Brixy et al. , 2012b). We think that the difference in fear of failure is explained by differences in the effect of role models on fear of failure in East and West Germany. Furthermore, we expect that social approval moderates the effect of having social interaction with entrepreneurs across East and West Germany. To be more precise, observing entrepreneurs should reduce fear of failure especially in West Germany (Hypothesis 1). This relationship is presumably significantly weaker in East Germany (Hypothesis 2).

This socialist heritage might not affect the actual approval of entrepreneurship equally among East Germans. Previous findings indicate that exposure to socialism increases mental East-West differ-

\footnotetext{
${ }^{3}$ Socialism also imprinted regional development. Fritsch (2004) illustrates that East and West Germany are marked by distinct regional growth regimes. Hence, the conditions for regional growth and entrepreneurship should be different (see also, Fritsch et al., 2014). Transition-specific adjustment processes might explain why East German regions have significantly lower economic capabilities and relatively more unfavorable long-term prospects than West German regions (e.g., Kronthaler, 2005; Uhlig, 2008).
} 
ences (e.g., Bauernschuster et al., 2012). Younger East Germans were partially raised in post-unification Germany and accordingly less exposed to the anti-entrepreneurial environment in socialism than older age cohorts. Negative perceptions of entrepreneurship might be passed on via intergenerational transmission, but the lack of direct exposure to the GDR certainly impacted the emerging share mental models differently across generations. Thus, for identifying the effect of low approval properly one should account for age (exposure to socialism). If approval of entrepreneurship matters for the effect of social interaction with entrepreneurs on fear of failure then respective differences between East and West Germans should be especially visible among older age groups.

\section{Empirical strategy}

\subsection{Data}

We are interested in the predictors of fear of failure. This individual-level variable comes from the representative Adult Population Surveys (APS) of the GEM project. The APS asks people whether or not they are engaged in entrepreneurship and also surveys several attitudes towards entrepreneurship in the general population. Because of its large scale, GEM data provides the opportunity to conduct analyses at the regional level in Germany as is demonstrated by other studies (e.g., Bergmann and Sternberg; 2007; Brixy et al., 2012; Stuetzer et al., 2014; Wagner and Sternberg, 2004). The GEM data for the present study refer to Germany, covering five years (2003-2006; 2008) ${ }^{4}$. A detailed description of the GEM methodology and data can be found in Reynolds et al. (2005) and in Bosma et al. (2012).

For our analysis, the sample is comprised of only non-entrepreneurial respondents. We did not consider respondents who have been entrepreneurs in the past and experienced a recent market exit. We also excluded all individuals who are entrepreneurs or are in the process of setting up a new business because we are interested in drivers of fear of failure among respondents who had not already opted for entrepreneurship. We contend that it is crucial to know about the drivers of fear of failure among non-entrepreneurs because fear of failure might reduce the emergence of entrepreneurial intentions. From an empirical point of view, the exclusion of all actual and former entrepreneurs from the analysis also allows a cleaner test of our hypotheses as we can isolate the effect of peers' levels of entrepreneurial experience on observers' fears of failure from the confounding effects of observers' own levels of experience.

We further restrict our analysis to respondents born in 1945 or later and being not older than the age of 59 at the time of the interview. Older respondents are unlikely to enter entrepreneurship

\footnotetext{
${ }^{4}$ Germany did not take part in the GEM 2007 cycle.
} 
as it is well known that "business creation is clearly concentrated among young and mid-career adults" (Reynolds, 2007, p. 36). This is due to the increasing risk aversion of older people and older individuals' preferences for economic activities that generate immediate income (e.g., paid employment) due to the short time horizon until retirement age (Lévesque and Minniti, 2006). We also did not include members of ethnic minorities since they were probably not socialized in East or West Germany. This also allows a cleaner test of our hypotheses.

\subsection{Dependent variable}

Our dependent variable is the revealed fear of failure regarding entrepreneurship. This is measured with the GEM question of whether fear of failure would prevent the respondent from starting a firm (binary variable: $1=$ yes, $0=$ no). The GEM fear of failure question is, to the best of our knowledge, the only available measure of fear of failure in large-scale datasets and has already been successfully used in previous studies. For example, Arenius and Minniti (2005) and Vaillant and Lafuente (2007) find that those individuals who reveal fear of failure are much less likely to be engaged in entrepreneurship. Several studies (Brixy et al., 2012; Hessels et al., 2011; Ramos-Rodriguez et al., 2012) report that fear of failure negatively influences individual's transitions through the entrepreneurial process and the level of start-up activity.

Note that there is some criticism regarding the construct validity of the single-item measure because the wording of the question suggests that avoidance (not starting a firm) is the sole outcome of fear of failure (Hayton et al., 2013). Arguably, fear of failure can also motivate people to work harder to avoid the failure event. However, a qualitative analysis of anxiety among entrepreneurs and nonentrepreneurs revealed that a motivating impact of fear is only present in those who are already engaged in entrepreneurship or had previous entrepreneurial experience. In contrast, a negative impact of fear was prevalent among non-entrepreneurs (Hayton et al., 2013). As our study analyzes the influence of entrepreneurial role models on non-entrepreneurs, the problem of construct validity seems to be less severe. Last but not least, we would like to note that we do not regard fear of failure as a proxy for general risk aversion.

\subsection{Independent variables}

Observing an entrepreneur is our main independent variable of interest. This GEM variable has been used in other studies examining peer effects (e.g., Vaillant and Lafuente, 2007; Wagner and Sternberg, 2004). As an alternative to this measure of knowing an entrepreneur, previous entrepreneurship literature has offered other potential proxies of entrepreneurial success, such as venture growth (Baum and Locke, 2004), profitability (e.g., Davidsson and Honig, 2003), and income (Åstebro and Thompson, 
2011) to name a few. Though these measures are all plausible, many of them are hard to observe and to evaluate as a person outside the business. Additionally, some of the success indicators are doubleedged swords. For example, empirical evidence suggests, on the one hand, that firms need to grow in order to reach the industry-specific minimum efficient size (MES) as soon as possible-the size that is needed for efficient operation in the respective market environment-and to overcome the liability of smallness and newness. If the growth of a new firm is too low, the entrepreneur has to exit the market soon (e.g., Audretsch, 1995; Mansfield, 1962). Thus, initial growth does not necessarily reflect success if firms are still far away from the MES. On the other hand, rapid growth is accompanied by great resource needs and stark organizational turmoil (Hambrick and Crozier, 1985). In particular, in young firms without profitable business models, rapid growth can deplete financial resources (Davidsson et al., 2009). These diametrically opposed effects create a problem for an observing individual on how to evaluate growth. Contrariwise, it is relatively easy to observe whether somebody entered the market successfully or not. In this respect, entering a market with a new firm is a clear signal to the observer that the entrepreneur (1) has successfully completed the start-up process and (2) at least thinks that he or she has a viable business idea with which to earn a living. Therefore, we operationalize whether a person observes a (successful) entrepreneur with a dummy variable based on the GEM-question whether the respondent knew someone who started a business in the past two years prior to the interview $(1=$ yes, $0=$ no). The GEM dataset does not allow testing for robustness with alternative success measures, as respondents are not asked about venture growth and the profitability of the firms of the entrepreneur(s) they have contact with. The lack of alternative success indicators is a limitation of our approach. At the same time our measure has the advantage that "being in the market" can be more easily observed and evaluated by an inexperienced non-entrepreneur than venture growth or changes in profitability over time.

Regarding our interaction hypotheses, we have stated above that we regard East Germany as an area with low approval of entrepreneurship while West Germany has a comparatively higher approval of entrepreneurship. The most straightforward test of our second hypothesis is interacting the indicator for knowing an entrepreneur with the East German dummy marker. Since both variables of interest (East German origin and knowing an entrepreneur) are dichotomous this requires constructing four different groups (Wooldridge, 2013, 230-238): (1) West Germans that know an entrepreneur; (2) West Germans that do not know an entrepreneur; (3) East Germans that know an entrepreneur; and (4) East Germans that do not know an entrepreneur.

The GEM data allows us to distinguish whether a respondent is located in East or West Germany at the date of the interview. However, no such information is available for the residence in 1989 just before the fall of the Berlin Wall, so we cannot control whether respondents are East German in 
origin but lived in West Germany at the time the interview was conducted or vice versa. Inner-German migrants might have a different level of fear of failure and might differently perceive start-up activity than individuals in their region of destination. However, we are confident that inner-German migrants did not have a significant influence on changes of the institutional approval in the area of destination. Although approximately 2.5 million East Germans migrated to West Germany in the first 20 years after reunification, the relative inflow when compared to the 60 million West Germans is rather small (4.1\%) (Institute of Population Research, 2013). Migration from West to East Germany was somewhat smaller in magnitude, and estimates from a representative sample of the German population suggest that $50 \%$ of these West-East migrants were return migrants (originally born in East Germany). Adjusting the raw numbers suggests that the true inflow from West to East Germany relative to the East German population is also rather small at less than $5 \%$ (Beck, 2004). Thus, we are confident that the migration bias in the data is negligible. An additional migration pattern helps us to further reduce the problem. Thirtytwo percent of the West-East migrants moved to Berlin, a region that we dropped from our sample because it is difficult to assign Berlin either to West or East Germany as before reunification Berlin was divided into a Western part (belonging to the Federal Republic of Germany) and an Eastern part (belonging to the German Democratic Republic).

\subsection{Controls}

We control for an array of variables at the level of the individual observer and the region he or she lives in. The aim of introducing these control variables is primarily to account for factors other than social contact with entrepreneurs that might drive individual fear of failure. Starting with the regional level, we control for the start-up rate, which is the number of start-ups divided by total employment in a region. Start-ups are defined as those establishments that appear for the first time in the Establishment History Panel (Betriebs-Historik-Panel, BHP) of the Institute for Employment Research (Institut für Arbeitsmarkt- und Berufsforschung, IAB). This data is based on the German Social Insurance Statistics and the first occurrence of establishments is determined by the first hire of employees that are obliged to pay Social Insurance contributions. Thus, the first hire of employees is regarded as the start-up event in the BHP data (for details, see Fritsch and Brixy, 2004). We do not consider unemployed individuals in the denominator as the start-ups we have information on comprise only genuine entrepreneurship in the sense of having at least one employee obliged to pay social insurance. Thus, we do not take into account pure necessity start-ups, which are more common among unemployed individuals. We believe that genuine or opportunity-driven start-ups are more likely to induce peer effects. This variable controls for the confounding effect that regional start-up activity in general drives the perception of fear of failure rather than the personal contact with an entrepreneur. 
We also control for socio-economic conditions of regions because they might not only affect the level of entrepreneurial activities but also entrepreneurial intentions and the legitimacy of entrepreneurship (e.g., Kibler et al., 2014). We also considered the economic prospects of regions because negative regional labor market prospects may imply negative individual labor market consequences in the case of a failed business attempt that may increase fear of failure. Therefore, we include the local unemployment rate and the level of GDP per capita. We also include population density, which we captured through four dummy variables, indicating the degree of agglomeration and centrality of regions. The respective classification is provided by the Federal Institute for Research on Building, Urban Affairs, and Spatial Development (Bundesinstitut fuer Bau-, Stadt- und Raumforschung, BBSR, 2011). These are "catch-all" variables for agglomeration (dis)economies that might influence the availability and access of resources and, therefore, the evaluation of whether or not entrepreneurial projects can be successful. Note that using an alternative measure of population density computed as population size divided by the size of the region does not change the results of the regressions.

We also include control variables at the individual level that might explain fear of failure. Following prior research in entrepreneurship, we use dummy variables for the highest achieved educational degree as an indicator for human capital (e.g., Davidsson and Honig, 2003). Furthermore, individual control variables are gender $(1=$ female, $0=$ male), whether respondents are currently in employment ( $1=$ yes, $0=$ no), and age of the individual (in years) (e.g., Driga et al., 2009; Koellinger et al., 2011; Wagner, 2007). We also include time dummies to indicate the year of the observation and to account for the potential impact of changing economic conditions on fear of failure. We also control for the role of household income as measured by 10 different categories. We argue that the relationship of income to fear of failure is non-linear. People with low incomes have nothing to lose, whereas individuals with high incomes have high opportunity costs for entrepreneurship. The definitions of all variables are summarized in Tables 1 and 2.

*** Tables 1 and 2 about here $* * *$

\section{Results}

\subsection{A first look into East-West differences}

Table $2 \mathrm{a}$ and $2 \mathrm{~b}$ highlight summary statistics and East-West mean differences (for a correlation matrix, see Table 3). Fear of failure is significantly higher among East German respondents. We do not find a difference that is statistically different from zero with respect to the proxy that indicates whether respondents have social contact with entrepreneurs. Thus, there is no systematic selection into having 
contact with entrepreneurs between East and West Germans. If we distinguish different age cohorts it becomes obvious that differences with respect to fear of failure are prevalent especially among older Germans. Thus, this particular East-West difference, which is also highlighted in the GEM country report Germany 2011 (Brixy et al., 2012b), is most pronounced for those age groups where East Germans were exposed to socialism for most of their life (Table 4). There are also differences with respect to individual control variables (see again Table 5). With respect to the regional control variables, there are some interesting East-West differences that reflect that regional conditions for entrepreneurship are quite different in both parts of the country (Fritsch, 2004). Unemployment is significantly higher in East German regions, and the reverse is true for GDP per capita. The start-up rate is higher in East Germany. In addition, the West German respondents live, on average, in more densely populated areas $^{5}$

\author{
*** Table 3 and 4 about here *** \\ *** Table 3 about here $* * *$
}

\title{
4.2 Regression results
}

We run logit regressions and cluster the standard errors on the level of planning regions (functional spatial economic units) in order to control for spatial autocorrelation and heteroskedasticity. ${ }^{6}$ In the first model fear of failure is regressed on knowing an entrepreneur and being an East German (Table 6 , column I). It is controlled for age, gender and survey wave fixed effects. The results show that knowing an entrepreneur reduces fear of failure significantly which is in line with our first hypothesis. Furthermore, East Germans seem to have a higher fear of failure as indicated already by the previously shown mean comparison tests. The relationship between age and fear of failure seems to follow an inverted $\mathrm{u}$-shape relationship. Thus, fear of failure increases with age in younger years while it is increasing at slower pace at older ages. ${ }^{7}$ Women are more likely to fear failure. In the second model (column II), we include further individual controls on education, household income, and employment status. Income is negatively related to fear of failure. Being active in the labor market is positively related to fear of failure. The dummy variables for education indicate that fear of failure decreases with the level of education (not shown for brevity). The coefficient size for knowing an entrepreneur

\footnotetext{
${ }^{5}$ This is indicated by the lower settlement structure type number where (1) is a highly agglomerated area. For example, $18 \%$ of all districts in West Germany are rural districts (type number $=4$ ) in rural regions, while this is $38 \%$ in East Germany.

${ }^{6}$ Because of the nested structure of our data (individuals in regions) multi-level models would be an alternative regression technique. However, likelihood ratio tests comparing multilevel models to standard logistic regressions reject the hypothesis of random effects, recommending the use of standard logistic regressions (Hox, 2010). Moreover, in the case of our paper results from multi-level models do not differ substantially from those of logistic regression. We, thus, use standard logistic regressions throughout the paper. For an assessment of regional start-up activity by means of multi-level modeling, see Hundt (2012).

${ }^{7}$ Based on the estimates the overall effect would turn to negative at an age of 76 years which is out of our sample range.
} 
and the East German dummy variable decrease slightly when introducing the individual characteristics but both remain significant. In column III regional control variables are added, which does not impact the coefficient estimates for the individual level variables. The regional start-up rate is negatively related to the individual level of fear of failure. Thus, the more entrepreneurial role models there are in a region, the lower the fear of failure among non-entrepreneurs. The coefficient estimates for GDP per capita and regional unemployment are insignificant. Altogether, knowing an entrepreneur reduces fear of failure among non-entrepreneurs regardless of controlling for an array of individual and regional characteristics. This finding supports our first hypothesis.

$* * *$ Table 6 about here $* * *$

For presenting the relationship between fear of failure, exposure to socialism, and social contacts with entrepreneurs in a convenient way and for making the effects more visible, we construct groups of individuals depending on their social contacts with entrepreneurs and their place of residence (East vs. West Germany). Since knowing an entrepreneur and place of residence are both dummy variables, building four groups is suited in methodological terms (Wooldridge, 2013, p. 230238). In the regression models presented in Table 7 we use West Germans that know an entrepreneur as reference group, which is compared to West Germans not knowing an entrepreneur, East Germans not knowing an entrepreneur, and East Germans knowing an entrepreneur. According to the model in column I of Table 7 the latter groups have a significantly higher level fear of failure as compared to West Germans with social contacts to entrepreneurs. As previously mentioned, not all East Germans were exposed in equal length to the socialist "treatment" (see chapter 2.3). Younger East Germans, for instance, that were in there twenties when the survey was conducted were partially raised in postunification Germany and it should be less likely that knowing entrepreneurs has a similar effect than for older East Germans. For this reason, we discriminate between older and younger East Germans in the further analysis. To this end, we interact the dummy variable for East Germans knowing an entrepreneur with the continuous age variable (column II) which reveals interesting insights. Firstly, the dummy variable for East Germans knowing an entrepreneur becomes insignificant. This finding suggests that there is not much of a difference between East and West Germans that know an entrepreneur when it comes to fear of failure in general. However, the interaction with age is significant and positive, as is age. Thus, for those East Germans knowing an entrepreneur, fear of failure increases with age as compared to other respondents. ${ }^{8}$

*** Table 7 about here $* * *$

\footnotetext{
${ }^{8}$ The results hardly differ when interacting the dummy marking West Germans not knowing an entrepreneur and the one for East Germans not knowing an entrepreneur with the age variable.
} 
There is also an age-related East-West difference when restricting the sample to respondents that know an entrepreneur but not when restricting the sample to those ones who do not know an entrepreneur. In this respect, the results for the sample of respondents knowing an entrepreneur in column III of Table 7 show that the probability to fear failure increases with age. As expected, the interaction between age and the East German dummy variable indicates indeed that the increase in fear of failure is particularly pronounced among East Germans. When repeating this test in the sample of respondents not knowing an entrepreneur (column IV) we find no age-related difference between East and West Germans. Thus, the models in column III and IV reveal that individuals having social contacts with entrepreneurs fear failure more in an environment with low approval as compared to their peers of the same age in a high approval environment. There is no such difference for individuals not having social contacts with entrepreneurs.

The different findings of the models in column III and IV rule out that fear of failure reflects a general pattern according to which leaving the current labor market status may be riskier for older people in East Germany as they have less opportunity to recoup potential costs of a failed business attempt. If this would be the case then one should see a higher fear of failure among older East Germans that do not know an entrepreneur as well. This is, however, not the case suggesting that differences in fear of failure among older East Germans are coupled to social contacts with entrepreneurs.

For making the results of the models in column II to IV more visible, we estimate the probability to fear a failure as a function of age. Figure $2 \mathrm{a}$ and $2 \mathrm{~b}$ refers to column II. The figures show the probability to fear failure of East Germans knowing an entrepreneur compared to other Germans. The plot shows an age gap that is widening. Figure 3a shows the plot for East and West Germans knowing entrepreneurs (based on column III). For a West German who is in his or her late 50s the probability of fearing to fail is 13 percentage points lower than for East Germans of the same age. The difference in the probability turns to be significant for the age of 42 years (see Figure $3 b$ ). Thus, older East Germans that know an entrepreneur have a significantly higher probability to fear failure compared to West Germans knowing an entrepreneur. Figure $4 a$ and $4 b$ (based on column IV), in turn, show that there is not much of an age-related difference in fear of failure among East and West Germans not knowing an entrepreneur. ${ }^{9}$

*** Figures 2-4 about here $* * *$

Another robustness check to show that exposure to socialism affects fear of failure is comparing the difference in effects only for older East and West Germans because only older East Germans

\footnotetext{
${ }^{9}$ Interpreting interaction terms in non-linear models is not straightforward. Using the more robust Ai et al. (2004) method confirms our initial interpretation. Results can be obtained upon request.
} 
have been extensively exposed to socialism. Therefore, we define East Germans born after 1975 as weakly treated group in terms of exposure to socialism. People in this age cohort spent part of their youth in the GDR but were not yet integrated in the labor market. These respondents did not experience the formative years of early adolescence under the socialist regime and are less likely to be effected by anti-capitalist indoctrination. Further support for this lower age limit comes from the research of developmental psychologists who show that (age appropriate) entrepreneurial competencies in early adolescence (ages 14-15) are an important driver for entrepreneurial intentions (Obschonka et al. 2010) and entrepreneurial success across their lifespan (Obschonka et al. 2011). We compare respondents born after 1975 first to a strongly treated group, namely those East Germans born between 1945 and 1960. The cohort dummy for the treatment group (older East Germans) is interacted with the proxy for knowing entrepreneurs. People born between 1960 and 1975 are not considered in the regression in order to get a clean distinction between strong vs. weak exposure to socialism. As it turns out, the interaction between the older East German cohort dummy and knowing an entrepreneur is significantly positive (Table 7 , column V). ${ }^{10}$ The size of the marginal effects show (knowing entrepreneurs $=1+$ East German $($ Born $<=1960)=1 \times$ knowing entrepreneurs $=-0.0716+0.0841$ $=+0.0125$ ) that knowing an entrepreneur does not reduce but even increase fear of failure among older East Germans. ${ }^{11}$ The predicted probability to fear failure among West Germans knowing an entrepreneur is about 42 percent whereas it is 14 percentage points higher for East Germans born prior to 1960 that know an entrepreneur.

In further models we extend the East German treatment group to those born until 1965. The difference in the coefficient estimates of knowing entrepreneurs is still significant but the size of the coefficients is smaller. The coefficient gets once more smaller when extending the treatment group further to 1970 and to 1975 . There is finally only a weakly significant difference when comparing all East Germans born prior to 1980 with those born in 1980 or later. These results suggest that knowing an entrepreneur makes a difference only for those East Germans that have been exposed to socialism for most of their life (Appendix Table A1). The decrease in the effect suggests that the influence of socialism plays only a minor role for younger people that spend a lot of their life in a market economy system.

Finally, in the model shown in column (VI) of Table 7, the sample is restricted to individuals born in 1960 or earlier. The interaction between the East German dummy and the proxy for knowing

\footnotetext{
10 Introducing an interaction term for the proxy for knowing an entrepreneur and the non-treated group of East Germans (those born in 1975 or later) does not change the significant effect for the treatment group. The interaction for younger East Germans itself is insignificant. This means that the effect of knowing an entrepreneur is not much different for younger East Germans as compared to West Germans that know an entrepreneur whereas there is a significant difference for older ones. 11 The results are similar when including a dummy variable for younger East Germans born after 1975.
} 
entrepreneurs is significant and positive adding up the entire effect to zero. The coefficient size increases when restricting the sample born in 1955 or earlier. Similarly it decreases when considering all Germans born until 1965, 1970, and 1975. This is in line with the previous results (Appendix Table A2). Altogether, knowing an entrepreneur is differently related to fear of failure only for those respondents that have been heavily exposed to an anti-entrepreneurial environment. Taken together, the results presented in Table 7 clearly supports Hypothesis 2 - observing an entrepreneur has a weaker effect on reducing fear of failure in regions with low approval of entrepreneurship than in high-approval regions.

\subsection{Fear of failure depends on institutions - consequences for entrepreneurial intentions}

After having established that institutional approval of entrepreneurship matters for fear of failure the questions remains whether there are indeed consequences for entrepreneurial choice. Therefore, we investigate in an additional analysis whether the relationships analyzed in the previous section translate into differences in entrepreneurial intentions. Looking at entrepreneurial intentions is justified because intentions are a necessary condition for future engagement in entrepreneurship. Non-entrepreneurs in our sample can be distinguished according to whether they expect to start a business (including any type of self-employment) within the next three years or not. We refer to the first group as having entrepreneurial intentions and to the second group as having no entrepreneurial intentions (see for a similar approach Stuetzer et al., 2014). Mean comparison tests for different age cohorts of East and West Germans (see Table 8) reveal that older East Germans are less likely to have entrepreneurial intentions while there is no significant difference for younger individuals. This finding is in line with a previous finding by Wyrwich (2013) that shows that older East Germans were less likely selfemployed than West Germans of the same age.

\section{*** Table 8 about here $* * *$}

In Table 9 we replicate the models in column I-IV of Table 7 but use entrepreneurial intentions as outcome instead of fear of failure. Additionally, we compare the previous models that are restricted either to respondents knowing an entrepreneur or not knowing an entrepreneur to specifications where it is not accounted for age interactions. The results resemble the findings for fear of failure. Older East Germans that know an entrepreneur are less likely to have entrepreneurial intentions. 
There is no such difference between younger East and West Germans. Controlling for fear of failure in the models would not alter the results on the main variables of interest (not reported). ${ }^{12}$

*** Table 9 about here $* * *$

\section{Discussion and conclusion}

The objective of this paper was to examine the effect of role models on fear to fail in observers. Taking a socio-economic perspective on fear of failure and applying a simple sender-receiver model, we argue that observing entrepreneurs decreases fear of entrepreneurial failure. Furthermore, we are also interested in the moderating effect of the institutional environment. By incorporating the concept of shared mental models into the sender-receiver model, we argue that the effect of role models is different in regions with low approval of entrepreneurship compared to high-approval regions because the receiver's interpretation of information transmitted by the sender often depends on the social context. More precisely, we argue that the effect of knowing an entrepreneur on reducing fear of failure should be weaker in regions with low approval of entrepreneurship compared to regions with high approval. We further argue that the mechanism behind this pattern is that the willingness to accept the behavior of entrepreneurial peers and the willingness to learn about entrepreneurial tasks by observing entrepreneurs is low if approval of entrepreneurship is low. We tested these hypotheses in the context of contemporary Germany, where entrepreneurship in the Eastern part is regarded as less accepted than in the Western part, which is related to the socialist legacy of East Germany.

We found that knowing an entrepreneur reduces other's fear to fail. This effect was stronger in West Germany but weaker for most people in East Germany. More precisely, while there was no differential effect of knowing an entrepreneur for younger East Germans, there were substantial differences for older East Germans. For the age group born before 1960 - that is those who were exposed most to the anti-entrepreneurial environment of socialism in East Germany - knowing an entrepreneur even slightly increases fear of failure. Our interpretation of this finding is that in low approval environments signals provided by entrepreneurial role models can be ignored or even adversely interpreted if they are not in line with the prevalent shared mental model regarding entrepreneurship. Consider, as a general example, the profit-maximizing entrepreneur. He or she can be either perceived as a contributor to social wealth or as an exploiter of labor, while the difference between both interpretations

\footnotetext{
12 Having entrepreneurial intentions is negatively correlated with fear of failure $(r=-0.1829)$ and significantly negative related to being a latent entrepreneur in the regressions. Fear of failure might of course determine the probability to have entrepreneurial intentions but it might be also the other way round. So, there is reverse causality and we do not want to interpret the models that "control" for fear of failure any further. The point that we want to drive home is that including fear of failure in the specifications of Table 4 would not change the coefficient estimates for the main variables of interest.
} 
depends just on whether the observer follows the ideology of Milton Friedman or Karl Marx (cf. Denzau and North, 1994).

One might argue that due to the communist history, older respondents in East Germany are less able to learn from the demonstrated entrepreneurship compared to younger East Germans. This should be a minor issue since we control for several individual characteristics. Nevertheless, we acknowledge that there might be some unobserved heterogeneity among respondents. Another problem might be that older East Germans might have social contact with entrepreneurs that provide poor opportunities to learn about entrepreneurship due to a lack of skills and knowledge in appropriately running a venture. This should be a minor issue as well since the most recent GEM wave for the year 2014 shows that the share of unsuccessful entrepreneurs (in terms of failed entrepreneurs) East German respondents have social contact with is similar to the share among West Germans. Therefore, potential differences in the ability of entrepreneurs East and West Germans have social contact with might not be an important driver of our results. ${ }^{13}$ Even if deficiencies regarding skills among older East Germans are in place, this would be most likely an effect of having spent a considerable amount of one's professional career in socialism where one could hardly acquire entrepreneurial skills (for details, see Wyrwich, 2013). Thus, lacking skills among East German entrepreneurs would be an indirect effect of extreme disapproval of entrepreneurship in the socialist period.

We acknowledge that this study has some limitations related to the GEM survey design. Positive responses to the GEM question "do you personally know someone who started a business in the past two years?" might not necessarily imply that these entrepreneurs are personal acquaintances of the entrepreneur (see also Bosma et al., 2012). Nevertheless, from our point of view, having the specific information of whether somebody started a firm in a clearly defined period of "the last two years" requires, in most cases, the existence of a personal link between the respondent and the person he or she has in mind when responding to the question. Another issue is that the GEM survey often measures constructs, such as fear of failure with a single item instead of an item battery, which implies some concerns regarding construct validity that we discussed in Section 3. A final limitation of our study is that GEM has information on the current residence of the respondent but not for their residence in 1989. However, as discussed in Section 3, the issue of inner German migration is small, and we excluded the Berlin region, which attracted a large share of these migrants.

Apart from these limitations, our analysis reveals interesting insights regarding the role of the institutional environment for entrepreneurial role modeling. It can thus inform the more general liter-

\footnotetext{
13 The results are not published in the official GEM report for the 2014 wave but can be obtained upon request.
} 
ature on institutions and entrepreneurship. Many of these studies have focused on the effect of cultural values, formal and informal institutions on entrepreneurial propensity (e.g., Davidsson, 1995; Freytag and Thurik, 2007), and innovation (e.g., Beugelsdijk, 2007; Shane, 1992). Our results provide a potential mechanism as to why there is less entrepreneurship in certain regions and countries than in others. In a recent paper Stuetzer et al. (2016) ascribe regional differences in entrepreneurial activity and culture in Great Britain to the long term presence of large-scale industries. In regions dominated by large-scale industries since the Industrial Revolution, there is today less entrepreneurial activity and a weaker entrepreneurship culture compared to other regions. These differences are probably due to the formation of low social approval of entrepreneurship. Our results also concur with recent empirical findings from Obschonka et al. (2015). They show that regional entrepreneurship culture moderates the effect of regional knowledge resources on regional start-up rates. Only if regions in the United States and Great Britain had a strong entrepreneurship culture, there was a positive relationship between knowledge and regional entrepreneurship. Our result is also in line with other research on the long lasting impact of communist indoctrination on individual preferences toward state reliance as opposed to self-reliance (e.g., Alesina and Fuchs-Schündeln, 2007; Bauernschuster et al., 2012). Furthermore, our results suggest that the effect of anti-capitalist indoctrination depends on exposure to socialism since the East-West difference is especially pronounced for individuals born before 1960 that spent 30 years or more under the socialist regime. For younger East Germans no differences to West Germans can be detected. Younger East Germans were less exposed to socialism. Accordingly, attitudes toward entrepreneurship and entrepreneurial failure are presumably not different between younger East and West Germans which is also indicated by mean comparison tests shown in this paper. Altogether, the paper shows that an assessment of the influence of socialist legacy on economic behavior should take into account individual exposure to socialism instead of focusing on general EastWest comparisons.

We would like to conclude with some implications of this study. To further investigate the moderating effect of the institutional environment, future research could study in more detail the indirect effects of formal and informal institutions on entrepreneurial perception and action. We might speculate that, for example, cultural differences affect opportunity perception and modes of exploitation of venture ideas. An extension of our approach could be to study the effect of firm failure on perceptual variables, entrepreneurial intentions, and action. If we take the socio-psychological dimension of role modeling seriously (see e.g., Fornahl, 2003; Sorenson and Audia, 2000), observing a lot of failure might make entrepreneurship a less attractive career option. Friends and acquaintances of a failing entrepreneur perceive his or her grief, loss of identity, and financial hardships. Recovery is neither automatic nor instantaneous (Shepherd, 2003), and thus, failed entrepreneurs might reduce the attractiveness of entrepreneurship as a career option. Applying this reasoning to the institutional 
context one can assume that this effect will be much stronger in communities where pursuing an entrepreneurial career is at odds with the shared mental model (low-approval communities) compared to communities with a high approval of entrepreneurship. Though some research has focused on entrepreneurial failure (e.g., Shepherd, 2003) and national differences in stigmatization of entrepreneurial failure (e.g., Lee et al., 2007), the regional dimension of failure and its potential effects remain largely unexplored (e.g., Cardon et al., 2011).

With regards to practice, our findings can inform public policies designed to encourage people to become entrepreneurs. Policy initiatives like campaigns that aim at increasing the awareness of entrepreneurship as a career option and the prevalence of entrepreneurial intentions via promoting entrepreneurs and enhancing the social interaction between entrepreneurs and non-entrepreneurs are pursued across countries (Lundström and Stevenson, 2005). Such policy measures may fall short in regions where social approval of entrepreneurship is low. Policy makers themselves should be aware that promoting entrepreneurial role models can be a harder challenge in some regions than in others. Therefore, an entrepreneurship policy that is tailored to regional conditions is warranted. However, in order to guide policy makers appropriately, much more research into the relationship between entrepreneurial role models, entrepreneurial perception, and institutional context is clearly needed.

\section{References}

Acs, Z.J., Mueller, P., 2008. Employment effects of business dynamics: Mice, gazelles and elephants, Small Business Economics, 30(1), 85-100.

Ai, C., Wang H., Norton, E.C., 2004. Computing interaction effects and standard errors in Logit and Probit models. The STATA Journal, 4, 154-167.

Alesina, A., Fuchs-Schuendeln, N., 2007. Good-bye Lenin (or not?): The effect of communism on people's preferences, American Economic Review, 97(4), 1507-1528.

Andersson, M., Koster, S., 2011. Sources of persistence in regional start-up rates - evidence from Sweden. Journal of Economic Geography, 11(1), 179-201.

Arenius, P., Minniti, M., 2005. Perceptual variables and nascent entrepreneurship. Small Business Economics, 24(3), 233-247.

Åstebro, T., Thompson, P., 2011. Entrepreneurs, Jacks of all trades or Hobos? Research Policy, 40(5), 637-349.

Audretsch, D.B., 1995. Innovation and Industry Evolution, Cambridge: MIT Press.

Bauernschuster, S., Falck, O., Gold, R., Heblich, S., 2012. The shadows of the socialist past: Lack of self-reliance hinders entrepreneurship. European Journal of Political Economy, 28(4), 2012, 485-497.

Baum, J.R., Locke, E.A., 2004. The relationship of entrepreneurial traits, skill, and motivation to subsequent venture growth. Journal of Applied Psychology, 89(4), 587-598.

Baumol, W.J., 1990. Entrepreneurship: productive, unproductive, and destructive. Journal of Political Economy, 98(5), 893-921.

Baumol, W.J., 2005. Education for Innovation: Entrepreneurial Breakthroughs versus Corporate Incremental Improvements. Innovation Policy and the Economy, 5, 33-56. 
Beck, G., 2004. Wandern gegen den Strom: West-Ost-Migration in Deutschland [Swim against the tide: WestEast migration in Germany], in: Frank Swiaczny und Sonja Haug (Eds.) Bevölkerungsgeographische Forschung zur Migration und Integration. Materialien zur Bevölkerungswissenschaft, Heft 112. Wiesbaden.

Bergmann, H., Sternberg, R., 2007. The changing face of entrepreneurship in Germany. Small Business Economics, 28(2-3), 205-221.

Beugelsdijk, S., 2007. Entrepreneurial culture, regional innovativeness and economic growth. Journal of Evolutionary Economics, 17(2), 187--210.

Bosma, N., Coduras, A., Litovsky, Y., Seaman, J. 2012. GEM Manual: A Report on the Design, Data and Quality Control of the Global Entrepreneurship Monitor (available at: http://www.gemconsortium.org).

Bosma, N., Hessels, J., Schutjens, V., Van Praag, M., Verheul, I., 2012. Entrepreneurship and role models. Journal of Economic Psychology, 33(2), 410-424.

Brixy, U., Sternberg, R., Stüber, H., 2012a. The selectiveness of the entrepreneurial process. Journal of Small Business Management, 50(1), 105-131.

Brixy, U., Sternberg, R., Vorderwülbecke, A., 2012b. Global Entrepreneurship Monitor (GEM). Länderbericht Deutschland 2011 [Country Report Germany 2011]. Hannover: Institut für Wirtschafts- und Kulturgeographie, Leibniz Universität Hannover, Nürnberg: Institut für Arbeitsmarkt- und Berufsforschung der Bundesagentur für Arbeit (IAB).

Brosig-Koch, J., Helbach, C., Ockenfels, A., Weimann, J., 2011. Still different after all these years: Solidarity behavior in East and West Germany. Journal of Public Economics, 95(11-12), 1373-1376.

Cacciotti, G. and J. C. Hayton (2015). Fear and entrepreneurship: A review and research agenda. International Journal of Management Reviews, 17(2), 165-190.

Cardon, M.S., Stevens, C.E., Potter, D.R., 2011. Misfortunes or mistakes? Cultural sensemaking of entrepreneurial failures. Journal of Business Venturing, 26(1), 79-92.

Chan, E.P.C., Chrisman, J.J., Kellermanns,F.W., 2011. The relationship between prior and subsequent new venture creation in the United States: a county level analysis. Journal of Business Venturing, 26(2), 200-211.

Chlosta, S., Patzelt, H., Klein, S.B., Dormann, C., 2012. Parental role models and the decision to become selfemployed: The moderating effect of personality. Small Business Economics, 38(1), 121-138.

Conroy, D.E., Elliot, A.J., 2004. Fear of failure and achievement goals in sport: Addressing the issue of the chicken and the egg. Anxiety, Stress \& Coping, 17(3), 271-285.

BBSR (2011), Laufende Raumbeobachtung - Raumabgrenzung [Continous Spatial Monitoring - Regional Boundaries], Bundesinstitut für Bau-, Stadt- und Raumforschunghttp://www.bbsr.bund.de/cln_032/nn_1067638/BBSR/DE/Raumbeobachtung/Rauma bgrenzungen/Kreistypen4/kreistypen.html.

Davidsson, P., 1995. Culture, structure and regional levels of entrepreneurship. Entrepreneurship \& Regional Development, 7(1), 41-62.

Davidsson, P., Honig, B., 2003. The role of human and social capital among nascent entrepreneurs. Journal of Business Venturing, 18(3), 301-331.

Davidsson, P., Steffens, P., Fitzsimmons, J., 2009. Growing profitable or growing from profits: putting the horse in front of the cart? Journal of Business Venturing, 24(4), 388-406.

Denzau, A.D., North, D.C., 1994. Shared mental models: Ideologies and institutions. Kyklos, 47(1), 3-31.

Driga, O., Lafuente, E., Vaillant, Y., 2009. Reasons for the relatively lower entrepreneurial activity levels of rural women in Spain. Sociologia Ruralis, 49(1), 70-96.

Dunn, T., Holtz-Eakin, D., 2000. Financial capital, human capital, and the transition to self-employment: evidence from intergenerational links. Journal of Labor Economics, 18(2), 282-305.

Earle, J. S., Sakova, Z., 2000. Business start-ups or disguised unemployment? Evidence on the character of selfemployment from transition economies, Labour Economics, 7(5), 575-601. 
Elliot, A.J., Harackiewicz, J.M., 1996. Approach and avoidance achievement goals and intrinsic motivation: A mediational analysis. Journal of Personality and Social Psychology, 70(3), 461-475.

Etzioni, A., 1987. Entrepreneurship, adatation and legitimation: a macro-behavioral perspective. Journal of Economic Behavior \& Organization, 8(2), 175-189.

Feldman, M. P. 2001. The entrepreneurial event revisited: Firm formation in a regional context. Industrial and Corporate Change, 10(4), 861-891.

Fornahl, D., 2003. Entrepreneurial activities in a regional context, in: Dirk Fornahl and Thomas Brenner (Eds): Cooperation, Networks, and Institutions in Regional Innovation Systems, Cheltenham: Edward Elgar, pp. 38-57.

Freytag, A., Thurik, R., 2007. Entrepreneurship and its determinants in a cross-country setting. Journal of Evolutionary Economics, 17(2), 117-131.

Fritsch, M., 2004. Entrepreneurship, entry and performance of new businesses compared in two growth regimes: East and West Germany. Journal of Evolutionary Economics, 14(5), 525-542.

Fritsch, M., Brixy, U., 2004. The establishment file of the German social insurance statistics. Zeitschrift für Wirtschafts- und Sozialwissenschaften, 124(1), 183-190.

Fritsch, M., Mueller, P., 2007. The persistence of regional new business formation-activity over time-Assessing the potential of policy promotion programs. Journal of Evolutionary Economics, 17(3), 299-315.

Fritsch, M., Bublitz, E., Rusakova, A., Wyrwich, M., 2014. How much of a socialist legacy? The reemergence of entrepreneurship in the East German transformation to a market economy. Small Business Economics, 43(2), 427-446.

Fritsch, M., Wyrwich, M., 2014. The long persistence of regional levels of entrepreneurship: Germany 19252005. Regional Studies, 48(6), 955-973.

Gertler, M., 2010. Rules of the game: The place of institutions in regional economic change. Regional Studies, 44(1), 1-15.

Hambrick, D.C., Crozier, L.M., 1985. Stumblers and stars in the management of rapid growth. Journal of Business Venturing, 1(1), 31-45.

Hayton, J.C., Cacciotti, G., Giazitzoglu, A., Mitchell, J.R., Ainge, C., 2013. Fear of failure in entrepreneurship: A cognitive process framework. Working paper presented at the 2013 BCERC conference, Lyon.

Hessels, J., Grilo, I., Thurik, R., van der Zwan, P., 2011. Entrepreneurial exit and entrepreneurial engagement. Journal of Evolutionary Economics, 21(3), 447-471.

Hox, J.J., 2010. Multilevel Analysis (2nd ed.). New York: Routledge.

Hundt, C. 2012. Zur Erklärung von Gründungsaktivitäten - Eine Mehrebenenanalyse aus individueller, regionaler und nationaler Perspektive [On the Explanation of Start-up Activities - A Multi-level Analysis from an Individual, a Regional and a National Perspective]. Münster: LIT-Verlag.

Institute of population research, 2013. Binnenwanderungen in Deutschland, http://www.bib-demografie.de/ DE/ZahlenundFakten/Wanderungen/Abbildungen/binnenwanderung.html, accessed 07.10.2013.

Kacperczyk, A., 2013. Social influence and entrepreneurship: The effect of university peers on entrepreneurial entry. Organization Science, 24(3), 664-683.

Kibler, E., Kautonen, T., Fink, M., 2014. Regional social legitimacy of entrepreneurship: implications for entrepreneurial intention and start-up behavior. Regional Studies, 48(6), 995-1015.

Koellinger, P., Minniti, M., Schade, C., 2011. Gender differences in entrepreneurial propensity. Oxford Bulletin of Economics and Statistics, 75(2), 213-234.

Kronthaler, F., 2005. Economic capability of East German regions: Results of a cluster analysis. Regional Studies, 39(6), 739-750.

Krueger, N.F., Reilly, M.D., Carsrud, A.L., 2000. Competing models of entrepreneurial intentions. Journal of Business Venturing, 15(5-6), 411-432. 
Lafuente, E., Vaillant, Y., Rialp, J., 2007. Regional differences in the influence of role models: Comparing the entrepreneurial process of rural catalonia. Regional Studies, 41(6), 779-795.

Landier, A., 2005. Entrepreneurship and the stigma of failure, Unpublished Working Paper, Stern School of Business, New York University. Available from http://papers.ssrn.com/sol3/papers.cfm?abstract id=850446.

Lee, S.-H., Peng, M.W., Barney, J.B., 2007. Bankruptcy laws and entrepreneurship development: A real options perspective. Academy of Management Review, 32(1), 257-272.

Lévesque, M., Minniti, M., 2006. The effect of aging on entrepreneurial behavior. Journal of Business Venturing 21(2), 177-194.

Lundström, A., Stevenson, L.A., 2005. Entrepreneurship Policy: Theory and Practice, Springer: New York.

Malecki, E.J., 2009. Geographical environments for entrepreneurship. International Journal of Entrepreneurship and Small Business, 7(2), 175-190.

Mansfield, E., 1962. Entry, Gibrat's law, innovation, and the growth of firms. American Economic Review, 52(5), 1023-1051.

Metzger, G., 2006. Afterlife - Who takes heart for restart. ZEW Discussion Paper No. 06-038.

Minniti, M., 2005. Entrepreneurship and network externalities. Journal of Economic Behavior and Organization, 57(1), 1-27.

Mueller, S.L., Thomas, A.S., 2001. Culture and entrepreneurial potential: A nine country study of locus of control and innovativeness. Journal of Business Venturing, 16(1), 51-75.

Mueller, P., van Stel, A., Storey, D.J., 2008, The effect of new firm formation on regional development over time: The case of Great Britain, Small Business Economics, 30(1), 59-71.

Nanda, R., Sørenson, J., 2010. Workplace peer effects and entrepreneurship. Management Science, 56(7), 1161126.

North, D.C., 1990. Institutions, Institutional Change and Economic Performance. Cambridge University Press, Cambridge.

Obschonka, M., Silbereisen, R.K., Schmitt-Rodermund, E., 2010. Entrepreneurial intention as developmental outcome. Journal of Vocational Behavior, 77(1), 63-72.

Obschonka, M., Silbereisen, R.K., Schmitt-Rodermund, E., Stuetzer, M., 2011. Nascent entrepreneurship and the developing individual: Early entrepreneurial competence in adolescence and venture creation success during the career. Journal of Vocational Behavior, 79(1), 121-133.

Obschonka, M., Schmitt-Rodermund, E., Silbereisen, R.K., Gosling, S.D., Potter, J., 2013. The Regional Distribution and Correlates of an Entrepreneurship-Prone Personality Profile in the United States, Germany, and the United Kingdom: A Socioecological Perspective, Journal of Personality and Social Psychology, 105(1), 104-122.

Obschonka, M., Stuetzer, M., Gosling, S.D., Rentfrow, P.J., Lamb, M.E., Potter, J., Audretsch, D.B., 2015. Entrepreneurial regions: Do macro-psychological cultural characteristics of regions help solving the “knowledge paradox" of economics? PLOS-ONE 10, e0129332, doi:10.1371/journal.pone.0129332.

Rainer, H., Siedler, R. 2009. Does democracy foster trust? Journal of Comparative Economics, 37(2), 251-269.

Ramos-Rodríguez, A.R., Medina-Garrido, J.A., Ruiz-Navarro, J., 2012. Determinants of hotels and restaurants entrepreneurship: A study using GEM data. International Journal of Hospitality Management, 31(2), 579-587.

Reynolds, P.D., Bosma, N., Autio, E., Hunt, S., De Bono, N., Servais, I., Lopez-Garcia, P., Chin, N., 2005. Global Entrepreneurship Monitor: Data collection design and implementation 1998-2003. Small Business Economics, 24(3), 205-231.

Reynolds, P.D., 2007. New firm creation in the United States: A PSED I overview. Foundations and Trends in Entrepreneurship, 3(1), 1-150.

Rodriguez-Pose, A., 2013. Do institutions matter for regional development? Regional Studies, 47(7), 1034-1047. 
Runst, P., 2013. Post-socialist culture and entrepreneurship. American Journal of Economics and Sociology, 72(3), 593-626

Schwartz, S.H., Bardi, A., 1997. Influence of adaptation to communist rule on value priorities in Eastern Europe. Political Psychology, 18(2), 385-410.

Scott, W. R., 1995. Institutions and Organizations, Sage: Thousand Oaks.

Shane, S.A., 1992. Why do some societies invent more than others? Journal of Business Venturing, 7(1), 29-46.

Shepherd, D.A., 2003. Learning from business failure: propositions of grief recovery for the self-employed. Academy of Management Review, 28(2), 318-328.

Smallbone, D., Welter, F., 2001. The distinctiveness of entrepreneurship in transition economies, Small Business Economics, 16(4), 249-262.

Sobel, R.S. 2008. Testing Baumol: Institutional quality and the productivity of entrepreneurship. Journal of Business Venturing 23(6), 641-655.

Sorenson, O., Audia, P.G., 2000. The Social Structure of Entrepreneurial Activity: Geographic Concentration of Footwear Production in the United States, 1940-1989. American Journal of Sociology, 106(2), 424-462.

Stuetzer, M., Obschonka, M., Brixy, U., Sternberg, R., Cantner, U., 2014. Regional characteristics, opportunity perception and entrepreneurial activities. Small Business Economics, 42(2), 221-244.

Stuetzer, M., Obschonka, M., Audretsch, D.B., Wyrwich, M., Rentfrow, P.J., Coombes, M., Shaw-Taylor, L., Satchell, M., 2016. Industry structure, entrepreneurship and culture: An empirical analysis using historical coalfields. European Economic Review, 86, 52-72.

Suchmann, M.C., 1995. Managing legitimacy: Strategic and institutional approaches. Academy of Management Review, 20(3), 571-611.

Uhlig, H., 2008. The slow decline of East Germany. Journal of Comparative Economics, 36(4), 517-541.

Vaillant, Y., Lafuente, E., 2007. Do different institutional frameworks condition the influence of local fear of failure and entrepreneurial examples over entrepreneurial activity? Entrepreneurship \& Regional Development, 19(4), 313-337.

Van Auken, H., Fry, F.L., Stephens, P., 2006. The influence of role models on entrepreneurial intentions. Journal of Developmental Entrepreneurship, 11(2),157-167.

Van Hoorn, Andre, Maseland, Robbert, 2010. Cultural differences between East and West Germany after 1991: Communist values versus economic performance?, Journal of Economic Behavior and Organization, 76(3), 791-804.

van Stel, A., Suddle, K., 2008. The impact of new firm formation on regional development in the Netherlands, Small Business Economics, 30(1), 31-47.

Wagner, J., 2007. What a difference a Y makes-Female and male nascent entrepreneurs in Germany. Small Business Economics, 28(1), 1-21.

Wagner, J., Sternberg, R., 2004. Start-up activities, individual characteristics, and the regional milieu: Lessons for entrepreneurship support policies from German micro data. Annals of Regional Science, 38(2), 219 240.

Westlund, H., Bolton, R., 2003. Local social capital and entrepreneurship. Small Business Economics, 21(2), 77113.

Wooldridge, J. M. (2013). Introductory Economics: A Modern Approach, 5th ed. Mason, OH: South-Western Cengage Learning.

Wyrwich, M., 2013. Can socioeconomic heritage produce a lost generation with regard to entrepreneurship?. Journal of Business Venturing, 28(5), 667-682.

Wyrwich, M. 2015. Entrepreneurship and intergenerational value transmission. Small Business Economics, 45(1), 191-213. 


\section{Tables and Figures}

Table 1: Individual-level variables (2003-2008)

\begin{tabular}{|c|c|}
\hline Variable & Definition \\
\hline Fear of failure & $\begin{array}{l}\text { Dummy: } 1 \text { = Participants stated that fear of failure would prevent them } \\
\text { from starting up. }\end{array}$ \\
\hline $\begin{array}{l}\text { Knowing } \\
\text { entrepreneurs }\end{array}$ & $\begin{array}{l}\text { Dummy: } 1 \text { = The participants personally knew someone who had } \\
\text { started a business within the last two years. }\end{array}$ \\
\hline Labor force & Dummy: 1 = Employed, unemployed, freelancer \\
\hline $\begin{array}{l}\text { Educational Attain- } \\
\text { ment }\end{array}$ & $\begin{array}{l}\text { The measure of educational attainment is based on the harmonized } \\
\text { categorical classification of participants' educational degree and voca- } \\
\text { tional attainment. The categories of educational attainment and the } \\
\text { respective years of schooling are: } 1=\text { no school leaving certificate ( } 7 \\
\text { years); } 2 \text { = primary or secondary school without vocational training ( } 8 \\
\text { years); } 3 \text { = primary or secondary school with vocational training ( } 10 \\
\text { years); } 4 \text { = secondary school without general qualification ( } 11 \text { years); } 5 \\
=\text { secondary school with general qualification (13 years); } 6=\text { post-sec- } \\
\text { ondary degree ( } 18 \text { years). }\end{array}$ \\
\hline Gender & Dummy: 1 = female. \\
\hline Age & Age of respondents in years. \\
\hline East & Dummy: Respondent lives in East Germany. \\
\hline Household income & $\begin{array}{l}\text { Categorical variable: } 1=\text { less than } 500 \text { euros; } 2=500 \text { to } 999 \text { euros; } 3= \\
1,000 \text { euros to } 1,499 \text { euros; } 4=1,500 \text { euros to } 1,999 \text { euros; } 5=2,000 \\
\text { euros to } 2,499 \text { euros; } 6=2,500 \text { euros to } 2,999 \text { euros; } 7=3,000 \text { euros } \\
\text { to } 3,499 \text { euros; } 8=3,500 \text { euros to } 3,999 \text { euros; } 9=4,000 \text { euros or } \\
\text { more. }\end{array}$ \\
\hline
\end{tabular}

Table 2: Regional-level variables (2003-2008)

\begin{tabular}{ll}
\hline Variable & Definition \\
\hline Start-up rate & Number of start-ups divided by number of employees. Source: In- \\
& stitute for Employment Research. \\
GDP per capita & GDP per capita in euros. Source: Federal Statistical Office. \\
Unemployment rate & Unemployment rate in percent. Source: Source: Institute for Em- \\
& ployment Research. \\
Settlement structure & Classification of German districts according to the degree of ag- \\
(population density) & glomeration and the centrality of regions. Four binary variables: \\
& I=Core city district in agglomerated or densely populated plan- \\
& ning regions, \\
& II=Densely populated district in densely populated planning re- \\
& gion, \\
& III=Rural districts in agglomeration and densely populated plan- \\
& ning regions, \\
& IV=Rural districts in rural planning regions. \\
& Source: The Federal Institute for Research on Building, Urban Af- \\
& fairs and Spatial Development (BBSR). \\
& \\
\hline
\end{tabular}


Table 3: East-West differences for individual and regional level variables (2003-2008)

\begin{tabular}{|c|c|c|c|c|c|}
\hline & \multicolumn{2}{|c|}{ East Germans } & \multicolumn{2}{|c|}{ West Germans } & \multirow{2}{*}{ Sig } \\
\hline & Mean & S.D. & Mean & S.D. & \\
\hline Fear of failure & 0.558 & 0.497 & 0.486 & 0.5 & $* * *$ \\
\hline Knowing entrepreneurs & 0.389 & 0.488 & 0.405 & 0.491 & n.s. \\
\hline Age in years & 40.596 & 11.186 & 39.866 & 11.234 & $* *$ \\
\hline Gender (Share of women) & 0.574 & 0.495 & 0.543 & 0.498 & $* *$ \\
\hline Average educational attainment & 4.315 & 1.102 & 4.225 & 1.215 & $* * *$ \\
\hline Labor force share & 0.816 & 0.388 & 0.775 & 0.417 & $* * *$ \\
\hline Household income & 4.503 & 2.106 & 5.527 & 2.199 & $* * *$ \\
\hline Start-up rate & 0.006 & 0.001 & 0.004 & 0.001 & $* * *$ \\
\hline Settlement structure type & 2.735 & 1.098 & 2.112 & 0.893 & $* * *$ \\
\hline GDP per capita & 0.018 & 0.004 & 0.027 & 0.01 & $* * *$ \\
\hline Unemployment rate & 19.061 & 3.173 & 8.735 & 2.865 & $* * *$ \\
\hline \multicolumn{6}{|c|}{$\begin{array}{l}\text { Notes: Sample comprises } 6,457 \text { West Germans and } 1,598 \text { East German observations. }{ }^{* * *} \\
\left(* *,{ }^{*}\right) \text { denotes a significance level of } 1 \%(5 \%, 10 \%) \text { for mean differences. The variables re- } \\
\text { fer to the time period } 2003 \text { to } 2008 \text {. For the values of variables see tables } 1 \mathrm{a} \text { and } 1 \mathrm{~b} \text {. } \\
\text { Source: Variables are based on GEM and on German Federal Statistics, German Social In- } \\
\text { surance Statistics. }\end{array}$} \\
\hline
\end{tabular}

Table 4: East-West differences: Fear of failure and knowing entrepreneurs across age cohorts

\begin{tabular}{|c|c|c|c|c|c|}
\hline & \multicolumn{2}{|c|}{ East Germans } & \multicolumn{2}{|c|}{ West Germans } & \multirow{2}{*}{ Sig } \\
\hline & Mean & S.D. & Mean & S.D. & \\
\hline Born $<=1960$ & \multicolumn{2}{|c|}{$N=661$} & \multicolumn{2}{|c|}{$\mathrm{N}=2,386$} & \\
\hline Fear of failure & 0.585 & 0.493 & 0.478 & 0.5 & $* * *$ \\
\hline Knowing entrepreneurs & 0.321 & 0.467 & 0.334 & 0.472 & n.s. \\
\hline Born $>1960$ and Born<=1975 & \multicolumn{2}{|c|}{$\mathrm{N}=639$} & \multicolumn{2}{|c|}{$\mathrm{N}=2,733$} & \\
\hline Fear of failure & 0.571 & 0.495 & 0.518 & 0.5 & $* *$ \\
\hline Knowing entrepreneurs & 0.419 & 0.494 & 0.435 & 0.496 & n.s. \\
\hline Born $>1975$ & \multicolumn{2}{|c|}{$\mathrm{N}=298$} & \multicolumn{2}{|c|}{$\mathrm{N}=1,338$} & \\
\hline Fear of failure & 0.47 & 0.5 & 0.437 & 0.496 & n.s. \\
\hline Knowing entrepreneurs & 0.477 & 0.5 & 0.471 & 0.499 & n.s. \\
\hline
\end{tabular}

Notes: ${ }^{* * *}\left(* *,{ }^{*}\right)$ denotes a significance level of $1 \%(5 \%, 10 \%)$ for mean differences. Source:

GEM Adult Population Survey Germany 2003-2008. 
Table 5: Correlation matrix

\begin{tabular}{|c|c|c|c|c|c|c|c|c|c|c|c|c|c|}
\hline & & [1] & {$[2]$} & [3] & [4] & [5] & {$[6]$} & [7] & [8] & [9] & {$[10]$} & {$[11]$} & [12] \\
\hline [1] & Fear of failure $=1$ & 1 & & & & & & & & & & & \\
\hline [2] & Knowing entrepreneurs $=1$ & $-0.085 * * *$ & 1 & & & & & & & & & & \\
\hline [3] & East German $=1$ & $0.057 * * *$ & -0.013 & 1 & & & & & & & & & \\
\hline [4] & Age in years & $0.036 * * *$ & $-0.127 * * *$ & $0.026 * *$ & 1 & & & & & & & & \\
\hline [5] & Female $=1$ & $0.125 * * *$ & $-0.116 * * *$ & $0.024 * *$ & $0.067 * * *$ & 1 & & & & & & & \\
\hline [6] & Educational attainment & $-0.113 * * *$ & $0.129 * * *$ & $0.028 * *$ & $-0.047 * * *$ & $-0.029 * * *$ & 1 & & & & & & \\
\hline [7] & Employed, freelancer, unemployed $=1$ & $0.048 * * *$ & $0.026^{* *}$ & $0.039 * * *$ & $0.215^{* * *}$ & $-0.111 * * *$ & $0.091 * * *$ & 1 & & & & & \\
\hline [8] & Household income & $-0.122 * * *$ & $0.114^{* * *}$ & $-0.184 * * *$ & $0.064 * * *$ & $-0.077 * * *$ & $0.262 * * *$ & $0.104^{* * *}$ & 1 & & & & \\
\hline [9] & Start-up rate & $0.019 *$ & -0.007 & $0.553 * * *$ & 0.015 & -0.002 & 0.004 & $0.022 * *$ & $-0.095^{* * *}$ & 1 & & & \\
\hline [10] & Settlement structure type & $0.034 * * *$ & 0 & $0.257 * * *$ & $0.059 * * *$ & 0 & $-0.096 * * *$ & $0.038 * * *$ & $-0.026 * *$ & $0.269 * * *$ & 1 & & \\
\hline [11] & GDP per capita & $-0.042 * * *$ & $0.024 * *$ & $-0.353 * * *$ & $-0.061 * * *$ & -0.003 & $0.075^{* * *}$ & $-0.033 * * *$ & $0.051 * * *$ & $-0.47 * * *$ & $-0.486 * * *$ & 1 & \\
\hline [12] & Unemployment rate & $0.048 * * *$ & $-0.023 * *$ & $0.814 * * *$ & $0.051 * * *$ & $0.02 *$ & $0.034 * * *$ & $0.033 * * *$ & $-0.188^{* * *}$ & $0.506^{* * *}$ & $0.113^{* * *}$ & $-0.254 * * *$ & 1 \\
\hline
\end{tabular}

Notes: $* * *(* *, *)$ denotes a significance level of $1 \%(5 \%, 10 \%)$. 
Table 6: Fear of Failure: individual and regional determinants

\begin{tabular}{|c|c|c|c|}
\hline & 1 & II & III \\
\hline Knowing entrepreneurs $=1$ & $\begin{array}{c}-0.0736 * * * \\
(0.0105)\end{array}$ & $\begin{array}{c}-0.0520 * * * \\
(0.0106)\end{array}$ & $\begin{array}{c}-0.0519 * * * \\
(0.0107)\end{array}$ \\
\hline East German $=1$ & $\begin{array}{c}0.0676^{* * *} \\
(0.0107)\end{array}$ & $\begin{array}{c}0.0535^{* * *} \\
(0.0109)\end{array}$ & $\begin{array}{c}0.0571 * * * \\
(0.0180)\end{array}$ \\
\hline Age in years & $\begin{array}{c}0.0264 * * * \\
(0.00359)\end{array}$ & $\begin{array}{c}0.0200 * * * \\
(0.00413)\end{array}$ & $\begin{array}{c}0.0201 * * * \\
(0.00415)\end{array}$ \\
\hline $\mathrm{Age}^{2}$ & $\begin{array}{c}-0.000332^{* * *} \\
(4.65 \mathrm{e}-05)\end{array}$ & $\begin{array}{c}-0.000263 * * * \\
(5.25 e-05)\end{array}$ & $\begin{array}{c}-0.000264 * * * \\
(5.27 \mathrm{e}-05)\end{array}$ \\
\hline Female $=1$ & $\begin{array}{c}0.109 * * * \\
(0.0103)\end{array}$ & $\begin{array}{c}0.108 * * * \\
(0.0104)\end{array}$ & $\begin{array}{c}0.108^{* * *} \\
(0.0104)\end{array}$ \\
\hline Employed, freelancer, unemployed $=1$ & - & $\begin{array}{c}0.0503 * * * \\
(0.0139)\end{array}$ & $\begin{array}{c}0.0498^{* * *} \\
(0.0139)\end{array}$ \\
\hline Household income & - & $\begin{array}{c}0.0273 * * \\
(0.0128)\end{array}$ & $\begin{array}{c}0.0258^{* *} \\
(0.0129)\end{array}$ \\
\hline Household income ${ }^{2}$ & - & $\begin{array}{c}-0.00411 * * * \\
(0.00112)\end{array}$ & $\begin{array}{c}-0.00398 * * * \\
(0.00112)\end{array}$ \\
\hline Dummy variables educational Degree $(n=6)$ & - & Yes** & Yes** \\
\hline Start-up rate & - & - & $\begin{array}{c}-0.0544 * * \\
(0.0234)\end{array}$ \\
\hline GDP per capita & - & - & $\begin{array}{l}-0.0188 \\
(0.0234)\end{array}$ \\
\hline Unemployment rate & - & - & $\begin{array}{c}0.0115 \\
(0.0175)\end{array}$ \\
\hline Observations & 8,055 & 8,055 & 8,055 \\
\hline Pseudo R-squared & 0.0228 & 0.0413 & 0.0420 \\
\hline Wald $\mathrm{Chi}^{2}$ & $292.3 * * *$ & $630.3 * * *$ & $642.9 * * *$ \\
\hline
\end{tabular}


Table 7: Fear of failure: The moderating effect of the institutional context

\begin{tabular}{|c|c|c|c|c|c|c|}
\hline & 1 & II & III & IV & $\mathrm{V}$ & $\mathrm{VI}$ \\
\hline & \multicolumn{2}{|c|}{ Full sample } & $\begin{array}{l}\text { Knowing entre- } \\
\text { preneurs }=1\end{array}$ & $\begin{array}{c}\text { Knowing entrepre- } \\
\text { neurs }=0\end{array}$ & $\begin{array}{c}\text { Age treatment } \\
\text { approach }\end{array}$ & Born $<=1960$ \\
\hline Knowing entrepreneurs $=1$ and $0=$ East German & Ref & Ref & Ref & - & - & - \\
\hline Knowing entrepreneurs $=1$ and $1=$ East German & $\begin{array}{c}0.0790 * * * \\
(0.0227)\end{array}$ & $\begin{array}{l}-0.0453 \\
(0.0655)\end{array}$ & $\begin{array}{l}-0.0823 \\
(0.0712)\end{array}$ & - & - & - \\
\hline Knowing entrepreneurs $=1$ and $1=$ East German $\times$ Age & & $\begin{array}{c}0.00323 * * \\
(0.00146)\end{array}$ & $\begin{array}{c}0.00379 * * \\
(0.00158)\end{array}$ & - & - & - \\
\hline Knowing entrepreneurs $=0$ and $0=$ East German & $\begin{array}{c}0.0592^{* * *} \\
(0.0118)\end{array}$ & $\begin{array}{c}0.0598^{* * *} \\
(0.0117)\end{array}$ & - & Ref & - & - \\
\hline Knowing entrepreneurs $=0$ and $1=$ East German & $\begin{array}{c}0.101 * * * \\
(0.0220)\end{array}$ & $\begin{array}{c}0.102 * * * \\
(0.0218)\end{array}$ & - & $\begin{array}{l}0.00588 \\
(0.0858)\end{array}$ & - & - \\
\hline Knowing entrepreneurs $=0$ and $1=$ East German $\times$ Age & - & - & - & $\begin{array}{c}0.00107 \\
(0.00192)\end{array}$ & - & - \\
\hline Knowing entrepreneurs $=1$ & - & - & - & - & $\begin{array}{c}-0.0716 * * * \\
(0.0150)\end{array}$ & $\begin{array}{c}-0.0689 * * * \\
(0.0203)\end{array}$ \\
\hline Knowing entrepreneurs $=1 \times 1=$ East German & - & - & - & - & - & $\begin{array}{c}0.0837^{* *} \\
(0.0368)\end{array}$ \\
\hline East German (Born<=1960)=1 × 1=Knowing entrepreneurs & - & - & - & - & $\begin{array}{c}0.0841^{* * *} \\
(0.0318)\end{array}$ & - \\
\hline East German (Born< $<1960)=1$ & - & - & - & - & $\begin{array}{l}0.0525^{*} \\
(0.0311)\end{array}$ & - \\
\hline East German=1 & - & - & - & - & - & $\begin{array}{l}0.0863^{* *} \\
(0.0342)\end{array}$ \\
\hline Age in years & $\begin{array}{l}0.0201^{* * *} \\
(0.00414)\end{array}$ & $\begin{array}{l}0.0198^{* * *} \\
(0.00417)\end{array}$ & $\begin{array}{l}0.0247^{* * *} \\
(0.00547)\end{array}$ & $\begin{array}{l}0.0162^{* * *} \\
(0.00572)\end{array}$ & $\begin{array}{l}0.0229 * * * \\
(0.00531)\end{array}$ & $\begin{array}{l}-0.0313 \\
(0.0437)\end{array}$ \\
\hline Age^2 $^{\wedge}$ & $\begin{array}{c}-0.000265^{* * *} \\
(5.26 \mathrm{e}-05)\end{array}$ & $\begin{array}{c}-0.000264^{* * *} \\
(5.28 \mathrm{e}-05)\end{array}$ & $\begin{array}{c}-0.000333^{* * *} \\
(6.80 \mathrm{e}-05)\end{array}$ & $\begin{array}{c}-0.000220 * * * \\
(7.26 \mathrm{e}-05)\end{array}$ & $\begin{array}{c}-0.000316^{* * *} \\
(6.87 \mathrm{e}-05)\end{array}$ & $\begin{array}{c}0.000227 \\
(0.000427)\end{array}$ \\
\hline Observations & 8,055 & 8,055 & 3,237 & 4,818 & 4,810 & 3,046 \\
\hline Pseudo R-squared & 0.0421 & 0.0424 & 0.0492 & 0.0327 & 0.0503 & 0.0550 \\
\hline Wald Chi2 & $639.1^{* * *}$ & $652.1^{* * *}$ & $266.9 * * *$ & $546.7 * * *$ & $615.8^{* * *}$ & $388.6 * * *$ \\
\hline
\end{tabular}

Notes: Robust standard errors in parentheses/ ${ }^{* * *} \mathrm{p}<0.01, * * p<0.05, * p<0.1$. Controls as in Table 6 column 3. Presenting marginal effects. Coefficient estimates are not shown for brevity. 

Table 8: East-West differences: entrepreneurial intention across age cohorts

\begin{tabular}{|c|c|c|c|c|c|}
\hline & \multicolumn{2}{|c|}{ East Germans } & \multicolumn{2}{|c|}{ West Germans } & \multirow[b]{2}{*}{ Sig } \\
\hline & Mean & S.D. & Mean & S.D. & \\
\hline Born $<=1960$ & \multicolumn{2}{|c|}{$N=661$} & \multicolumn{2}{|c|}{$\mathrm{N}=2,386$} & \\
\hline Entrepreneurial intention & 0.047 & 0.212 & 0.079 & 0.269 & $* * *$ \\
\hline Born $>1960$ and Born<=1975 & \multicolumn{2}{|c|}{$\mathrm{N}=639$} & \multicolumn{2}{|c|}{$\mathrm{N}=2,733$} & \\
\hline Entrepreneurial intention & 0.117 & 0.322 & 0.130 & 0.336 & n.s. \\
\hline Born $>1975$ & \multicolumn{2}{|c|}{$\mathrm{N}=298$} & \multicolumn{2}{|c|}{$\mathrm{N}=1,338$} & \\
\hline Entrepreneurial intention & 0.205 & 0.404 & 0.169 & 0.375 & n.s. \\
\hline
\end{tabular}

Notes: $* *(* *, *)$ denotes a significance level of $1 \%(5 \%, 10 \%)$ for mean differences. 
Table 9: Entrepreneurial intentions: the moderating effect of the institutional context

\begin{tabular}{|c|c|c|c|c|c|c|}
\hline & \multirow[b]{2}{*}{ Full } & \multirow[b]{2}{*}{ mple } & \multirow{2}{*}{\multicolumn{2}{|c|}{$\begin{array}{c}\text { III } \quad \text { IV } \\
\text { Knowing entrepreneurs=1 }\end{array}$}} & \multirow{2}{*}{\multicolumn{2}{|c|}{$\begin{array}{cc}\mathrm{V} & \mathrm{VI} \\
\text { Knowing entrepreneurs }=0\end{array}$}} \\
\hline & & & & & & \\
\hline $\begin{array}{l}\text { Knowing entrepreneurs }=1 \text { and } 0=\text { East German (West Ger- } \\
\text { man) }\end{array}$ & Ref & Ref & Ref & Ref & - & - \\
\hline Knowing entrepreneurs $=1$ and 1 East German & $\begin{array}{l}0.00222 \\
(0.0146)\end{array}$ & $\begin{array}{c}0.0855^{* *} \\
(0.0387)\end{array}$ & $\begin{array}{c}0.0141 \\
(0.0285)\end{array}$ & $\begin{array}{l}0.159 * * \\
(0.0634)\end{array}$ & - & - \\
\hline Knowing entrepreneurs $=1$ and $1=$ East German $\times$ Age & - & $\begin{array}{c}-0.00236^{* *} \\
(0.00107)\end{array}$ & - & $\begin{array}{c}-0.00411^{* *} \\
(0.00175)\end{array}$ & - & - \\
\hline $\begin{array}{l}\text { Knowing entrepreneurs }=0 \text { and } 0=\text { East German (West Ger- } \\
\text { man) }\end{array}$ & $\begin{array}{l}-0.106^{* * *} \\
(0.00904)\end{array}$ & $\begin{array}{r}-0.107^{* * *} \\
(0.00900)\end{array}$ & - & - & Ref & Ref \\
\hline Knowing entrepreneurs $=0$ and $1=$ East German & $\begin{array}{c}-0.132^{* * *} \\
(0.0193)\end{array}$ & $\begin{array}{c}-0.132^{* * *} \\
(0.0193)\end{array}$ & - & - & $\begin{array}{l}-0.0232 \\
(0.0145)\end{array}$ & $\begin{array}{l}0.00419 \\
(0.0276)\end{array}$ \\
\hline Knowing entrepreneurs $=0$ and $1=$ East German $\times$ Age & - & - & - & - & & $\begin{array}{l}-0.000736 \\
(0.000599)\end{array}$ \\
\hline Age & $\begin{array}{c}0.00675^{* * *} \\
(0.00228)\end{array}$ & $\begin{array}{c}0.00712 * * * \\
(0.00232)\end{array}$ & $\begin{array}{c}0.00616 \\
(0.00478)\end{array}$ & $\begin{array}{c}0.00697 \\
(0.00492)\end{array}$ & $\begin{array}{c}0.00694^{* * *} \\
(0.00261)\end{array}$ & $\begin{array}{c}0.00707^{* * *} \\
(0.00264)\end{array}$ \\
\hline $\mathrm{Age}^{2}$ & $\begin{array}{c}-0.000118^{* * *} \\
(3.11 \mathrm{e}-05)\end{array}$ & $\begin{array}{c}-0.000119^{* * *} \\
(3.16 \mathrm{e}-05)\end{array}$ & $\begin{array}{c}-0.000130^{* *} \\
(6.50 \mathrm{e}-05)\end{array}$ & $\begin{array}{c}-0.000131^{* *} \\
(6.66 \mathrm{e}-05)\end{array}$ & $\begin{array}{c}-0.000105^{* * *} \\
(3.44 \mathrm{e}-05)\end{array}$ & $\begin{array}{c}-0.000105^{* * *} \\
(3.46 \mathrm{e}-05)\end{array}$ \\
\hline Observations & 8,055 & 8,055 & 3,237 & 3,237 & 4,818 & 4,818 \\
\hline Pseudo R-squared & 0.0956 & 0.0965 & 0.0374 & 0.0393 & 0.0534 & 0.0537 \\
\hline Wald $\mathrm{Chi}^{2}$ & $590.6 * * *$ & $608.9 * * *$ & $134.0^{* * *}$ & $147.2^{* * *}$ & $230.7 * * *$ & $256.1^{* * *}$ \\
\hline
\end{tabular}

Robust standard errors in parentheses/ ${ }^{* * *} p<0.01,{ }^{* *} p<0.05,{ }^{*} p<0.1$. Controls as in Table 6 column 3. Presenting marginal effects. Coefficient estimates are not shown for brevity. 

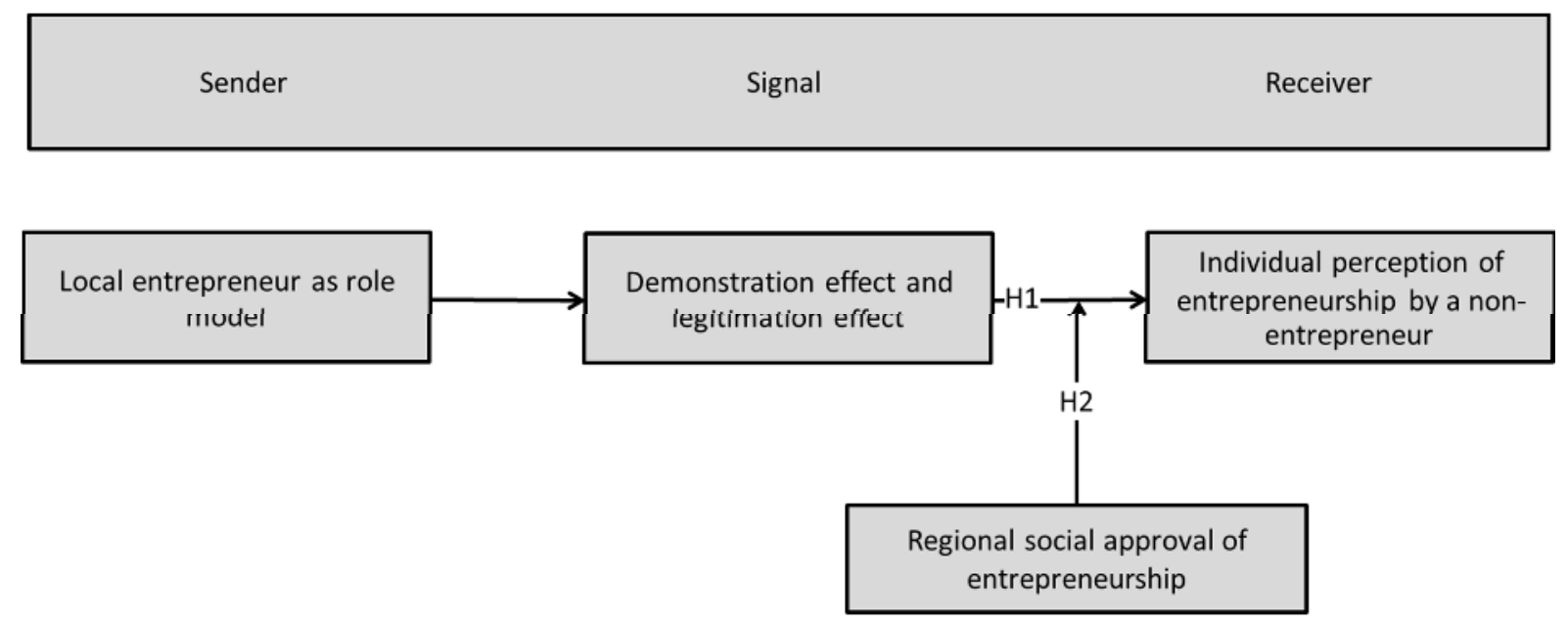

Figure 1: Extended sender-receiver model 

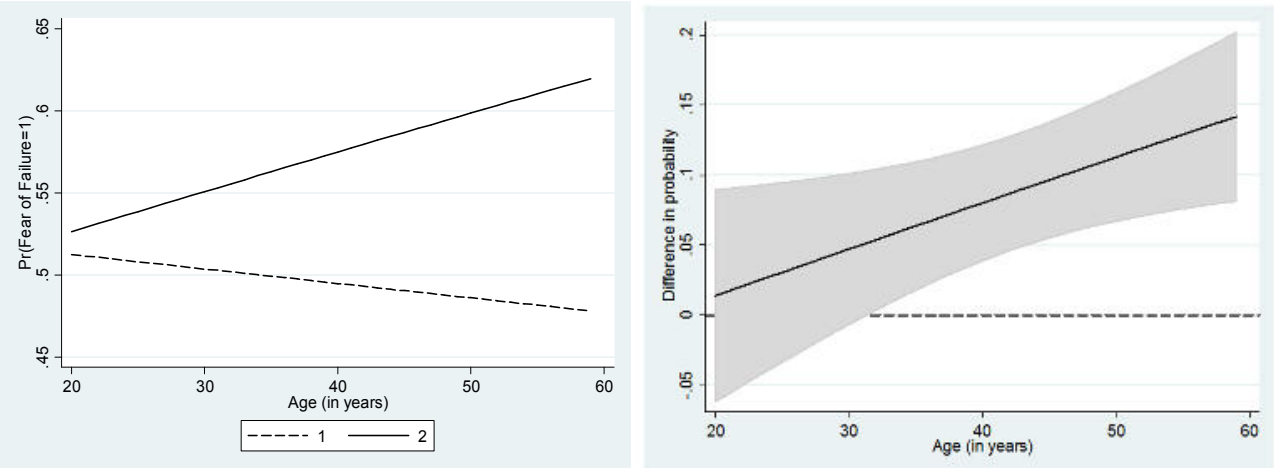

Figure 2a and 2b: Probability of fear of failure and differences in probability across groups of respondents (based on Table 5, column II).

(1: West German + East German and not knowing an entrepreneur)

(2: East German and knowing an entrepreneur) (Shaded area: 95\% confidence interval).
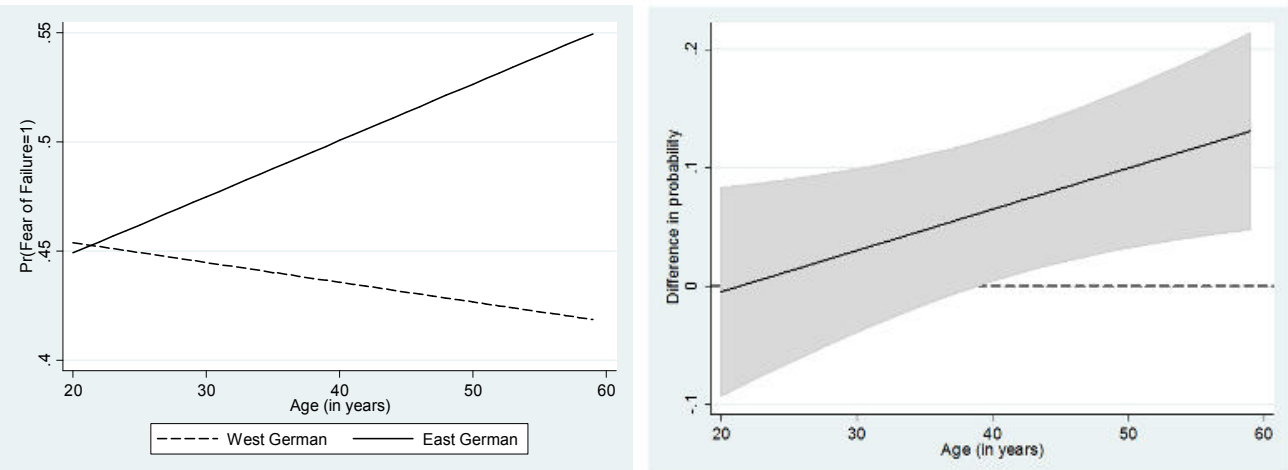

Figure $3 \mathrm{a}$ and $3 \mathrm{~b}$ : Probability of fear of failure and differences in probability among East and West Germans knowing an entrepreneur (based on Table 5, column III) (Shaded area: 95\% confidence interval).
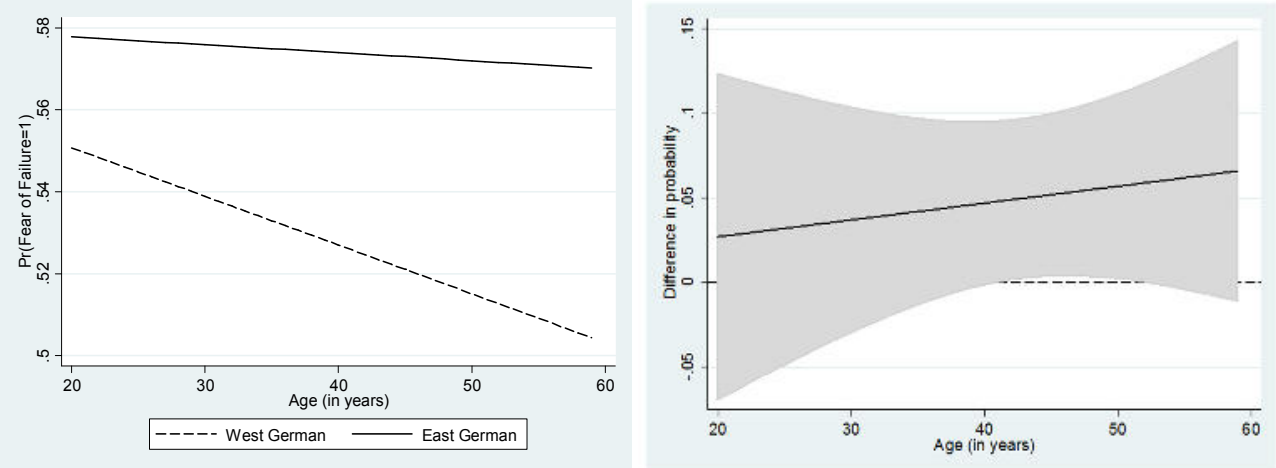

Figure 4a and 4b: Probability of fear of failure and differences in probability among East and West Germans not knowing an entrepreneur (based on Table 5, column IV) (Shaded area: 95\% confidence interval). 


\section{Appendix Tables}

Table A1: Age treatment approach for different age groups

\begin{tabular}{|c|c|c|c|c|}
\hline & 1 & II & III & IV \\
\hline & . & . & . & . \\
\hline \multirow[t]{2}{*}{ Knowing entrepreneurs $=1$} & $-0.0848 * * *$ & $-0.0632 * * *$ & $-0.0597 * * *$ & $-0.0593 * * *$ \\
\hline & $(0.0184)$ & $(0.0135)$ & $(0.0116)$ & $(0.0116)$ \\
\hline \multirow[t]{2}{*}{ East German (Born<=1955)=1 x 1=Knowing entrepreneurs } & $0.113^{* * *}$ & & & \\
\hline & $(0.0376)$ & & & \\
\hline \multirow[t]{2}{*}{ East German (Born<=1955)=1 } & 0.0405 & & & \\
\hline & $(0.0414)$ & & & \\
\hline \multirow[t]{2}{*}{ East German (Born<=1965)=1 x 1=Knowing entrepreneurs } & & $0.0776 * * *$ & & \\
\hline & & $(0.0244)$ & & \\
\hline \multirow[t]{2}{*}{ East German (Born<=1965) $=1$} & & 0.0322 & & \\
\hline & & $(0.0265)$ & & \\
\hline \multirow[t]{2}{*}{ East German (Born<=1975)=1 x 1=Knowing entrepreneurs } & & & $0.0535^{* *}$ & \\
\hline & & & $(0.0257)$ & \\
\hline \multirow[t]{2}{*}{ East German (Born<=1975) $=1$} & & & 0.0241 & \\
\hline & & & $(0.0218)$ & \\
\hline \multirow[t]{2}{*}{ East German (Born<=1980)=1 x 1=Knowing entrepreneurs } & & & & $0.0424 *$ \\
\hline & & & & $(0.0235)$ \\
\hline \multirow[t]{2}{*}{ East German (Born<=1980) $=1$} & & & & $0.0433^{* *}$ \\
\hline & & & & $(0.0203)$ \\
\hline \multirow[t]{2}{*}{ Age in years } & $0.0279 * * *$ & $0.0206 * * *$ & $0.0187^{* * *}$ & $0.0188 * * *$ \\
\hline & $(0.00645)$ & $(0.00458)$ & $(0.00422)$ & $(0.00423)$ \\
\hline \multirow[t]{2}{*}{$\mathrm{Age}^{2}$} & $-0.000382 * * *$ & $-0.000281^{* * *}$ & $-0.000250 * * *$ & $-0.000250 * * *$ \\
\hline & (8.27e-05) & (5.90e-05) & $(5.34 \mathrm{e}-05)$ & $(5.36 \mathrm{e}-05)$ \\
\hline Observations & 3,533 & 6,048 & 8,055 & 8,055 \\
\hline Pseudo R-squared & 0.0506 & 0.0461 & 0.0420 & 0.0423 \\
\hline Wald $\mathrm{Chi}^{2}$ & $504.6 * * *$ & $826.4^{* * *}$ & $707.6 * * *$ & $663.5^{* * *}$ \\
\hline
\end{tabular}


Table A2: Models including respondents of different age cohorts

\begin{tabular}{|c|c|c|c|c|}
\hline & 1 & II & III & IV \\
\hline & Born< $<=1955$ & Born $<=1965$ & Born $<=1975$ & Born< $<=1980$ \\
\hline \multirow{2}{*}{ Knowing entrepreneurs $=1$} & $-0.0985 * * *$ & $-0.0561 * * *$ & $-0.0554 * * *$ & $-0.0545^{* * *}$ \\
\hline & $(0.0290)$ & $(0.0173)$ & $(0.0146)$ & $(0.0137)$ \\
\hline \multirow[t]{2}{*}{ Knowing entrepreneurs $=1 \times 1=$ East German } & $0.134 * * *$ & $0.0711 * *$ & $0.0564 * *$ & 0.0370 \\
\hline & $(0.0445)$ & $(0.0279)$ & $(0.0258)$ & $(0.0245)$ \\
\hline \multirow[t]{2}{*}{ East German=1 } & 0.0568 & $0.0566 * *$ & $0.0470 * *$ & $0.0518^{* *}$ \\
\hline & $(0.0473)$ & $(0.0264)$ & $(0.0211)$ & $(0.0209)$ \\
\hline \multirow[t]{2}{*}{ Age in years } & 0.181 & 0.0334 & $0.0308^{* * *}$ & $0.0189 * * *$ \\
\hline & $(0.117)$ & $(0.0250)$ & $(0.00948)$ & $(0.00619)$ \\
\hline \multirow[t]{2}{*}{ Age $^{2}$} & -0.00174 & -0.000399 & $-0.000374 * * *$ & $-0.000248 * * *$ \\
\hline & (0.00109) & $(0.000255)$ & $(0.000107)$ & $(7.37 e-05)$ \\
\hline Observations & 1,896 & 4,411 & 6,417 & 7,111 \\
\hline Pseudo R-squared & 0.0607 & 0.0459 & 0.0405 & 0.0385 \\
\hline Wald $\mathrm{Chi}^{2}$ & $289.0 * * *$ & $547.8^{* * *}$ & $466.2^{* * *}$ & $470.5^{* * *}$ \\
\hline
\end{tabular}

Notes: Robust standard errors in parentheses/ $* * * p<0.01, * * p<0.05, * p<0.1$. Controls as in Table 6 column 3. Presenting marginal effects. Coefficient estimates are not shown for brevity. 